\title{
Soluble Trace Elements and Total Mercury in Arctic Alaskan Snow
}

\author{
ELAINE SNYDER-CONN,${ }^{1}$ JOHN R. GARBARINO,${ }^{2}$ GERALD L. HOFFMAN ${ }^{2}$ and ALAN OELKERS ${ }^{3}$
}

(Received 25 September 1996; accepted in revised form 21 March 1997)

\begin{abstract}
Ultraclean field and laboratory procedures were used to examine trace element concentrations in northern Alaskan snow. Sixteen soluble trace elements and total mercury were determined in snow core samples representing the annual snowfall deposited during the 1993-94 season at two sites in the Prudhoe Bay oil field and nine sites in the Arctic National Wildlife Refuge (Arctic NWR). Results indicate there were two distinct point sources for trace elements in the Prudhoe Bay oil field—a source associated with oil and gas production and a source associated with municipal solid-waste incineration. Soluble trace element concentrations measured in snow from the Arctic NWR resembled concentrations of trace elements measured elsewhere in the Arctic using clean sample-collection and processing techniques and were consistent with deposition resulting from widespread arctic atmospheric contamination. With the exception of elements associated with sea salts, there were no orographic or east-west trends observed in the Arctic NWR data, nor were there any detectable influences from the Prudhoe Bay oil field, probably because of the predominant easterly and northeasterly winds on the North Slope of Alaska. However, regression analysis on latitude suggested significant south-to-north increases in selected trace element concentrations, many of which appear unrelated to the sea salt contribution.
\end{abstract}

Key words: snow, Prudhoe Bay, Arctic National Wildlife Refuge, trace element concentrations, point sources

RÉSUMÉ. Des techniques ultra-propres utilisées sur le terrain et en laboratoire ont permis d'étudier les concentrations en éléments traces dans la neige de l'Alaska septentrional. Seize éléments traces solubles et le mercure total ont été mesurés dans des carottes de neige représentant la chute nivale annuelle de la saison 1993-94 à deux emplacements du champ pétrolifère de Prudhoe Bay et à neuf emplacements du refuge faunique national Arctique. Les résultats révèlent qu'il existe deux sources ponctuelles distinctes d'éléments traces découverts dans le champ pétrolifère de Prudhoe Bay, l'une reliée à la production de pétrole et de gaz et l'autre reliée à l'incinération des déchets municipaux solides. Les concentrations en éléments traces solubles mesurées dans la neige du refuge faunique national Arctique s' apparentaient aux concentrations en éléments traces mesurées ailleurs dans l'Arctique à l'aide de techniques propres de prélèvement et de traitement des carottes. Ces concentrations correspondent bien à des dépôts engendrés par une pollution atmosphérique généralisée dans l'Arctique. À l'exception des éléments associés aux sels marins, on n'a observé aucune tendance orographique ou est-ouest dans les données du refuge faunique national Arctique, de même qu'on n'a pas décelé d'influences perceptibles dues au champ pétrolifère de Prudhoe Bay, probablement en raison des vents prédominants d'est et du nord-est sur le versant nord de l'Alaska. L'analyse de régression sur la latitude suggère cependant une augmentation importante en allant du sud au nord dans les concentrations en certains éléments traces, dont beaucoup ne semblent pas reliées à l'apport de sel marin.

Mots clés: neige, Prudhoe Bay, refuge faunique national Arctique, concentrations en éléments traces, sources ponctuelles

Traduit pour la revue Arctic par Nésida Loyer.

\section{INTRODUCTION}

The Arctic atmosphere is an important reservoir for atmospheric contaminants from agricultural and industrial regions of the Northern Hemisphere, including fly ash, heavy metals, nitrogen and sulfur compounds, radionuclides, polycyclic aromatic hydrocarbons, and pesticides (Thomas, 1973; Kerr, 1979, 1981; Rahn and McCaffrey, 1979a, b, 1980; Barrie et al., 1981, 1985; Daisey et al., 1981; Rahn, 1981; Rahn et al., 1981; Shaw, 1982, 1991a, b; Barrie and Vet,
1984; Barrie, 1986; Rahn and Lowenthal, 1986; Jaffe, 1991; Jaffe et al., 1991; Landsberger et al., 1992; Li, 1993). Global distillation and volatilization processes contribute many contaminants to the Arctic in gaseous form (Goldberg, 1975, 1976; Oehme, 1982; Khalil and Rasmussen, 1983, 1984; Rasmussen et al., 1983; Rasmussen and Khalil, 1984; Slemr and Langer, 1992; Iwata et al., 1993). However, most trace element pollutants are associated with submicron aerosols transported in air masses during late winter and early spring. Such aerosols contribute to arctic haze, resulting in

\footnotetext{
${ }^{1}$ U.S. Fish and Wildlife Service, Northern Alaska Ecological Services, 101 12th Avenue, Fairbanks, Alaska 99701, U.S.A.; present address: U.S. Fish and Wildlife Service, Klamath Falls Ecosystem Restoration Office, 6600 Washburn Way, Klamath Falls, Oregon 97603, U.S.A.

${ }^{2}$ U.S. Geological Survey, National Water Quality Laboratory, 5293 Ward Road, M.S. 407, Arvada, Colorado 80002, U.S.A; jrgarb@usgs.gov

${ }^{3}$ Macalester College, 1600 Grand Avenue, Saint Paul, Minnesota 55105, U.S.A.
} 
reduced visibility (Shaw and Stamnes, 1980; Wallen, 1986) and pollutant concentrations of 10 to 100 times normal levels (Rahn and McCaffrey, 1979a, b, 1980; Rahn and Lowenthal, 1986).

The principal source area of pollutants to arctic Alaska has been traced to central and western Asia (Shaw, 1976, 1982; Kerr, 1979, 1981; Barrie et al., 1981; Lowenthal and Rahn, 1985; Rahn and Lowenthal, 1986). Other important source regions, deduced from back trajectories and trace element ratios (involving arsenic, antimony, indium, selenium, zinc, and noncrustal manganese and vanadium), are the United Kingdom and Europe. Europe also appears to have provided almost half the sulfate in at least some of the arctic haze episodes (Lowenthal and Rahn, 1985). Only a small fraction of the pollutants in Alaskan haze originate from southern Canada and the United States (Rahn and Lowenthal, 1986). However, the contributions to northern Alaska from local sources, such as North Slope oil fields and windblown loess, have received only limited assessment (BP Exploration Alaska, Inc., 1991; Jaffe, 1991; Jaffe et al., 1991; Jaffe and Zukowski, 1993).

Few studies have addressed the fate of contaminants in the Arctic. Atmospheric chemists have assumed low transfer rates to arctic ecosystems because arctic wet precipitation rates are low, and the dry deposition rate for the predominant aerosol-size range $(0.05-1 \mu \mathrm{m})$ is weak (Junge, 1977; Kerr, 1979; Heintzenberg, 1989). However, Landsberger et al. (1992) have suggested that snowflakes, because of their larger size and slower fall rate compared to rain, might accumulate more air pollutants. Increasing evidence of high organochlorine pesticide and mercury concentrations in arctic marine mammals and fish (Bowes and Jonkel, 1975; Herron et al., 1977; Wright and Dovland, 1978; Heintzenberg and Larssen, 1983; McNeely and Gummer, 1984; Davidson et al., 1985, 1987, 1989; Wolff and Peel, 1985, 1988; Bidleman et al., 1990; Gregor, 1990; Welch et al., 1991) indicates that the atmosphere may provide an effective mechanism for the transfer of certain pollutants to marine ecosystems. Other possible mechanisms include transfer of pollutants from riverine systems.

The fate of atmospheric contaminants in terrestrial ecosystems, particularly in arctic Alaska, is less well known than their fate in marine ecosystems, but may also be significant (Weiss et al., 1975; Jaffe and Zukowski, 1993; Ford et al., 1995). Barrie et al. (1985) observed that the conductivity of an ice core from northern Ellesmere Island, Northwest Territories, Canada, increased 75\% from 1956 to 1977. Increased acidification of snow, which is likely to increase rates of release of metals from sediments and rocks, also has been observed during the past 20 years (Wolff and Peel, 1985; Wallen, 1986), although there are discrepancies on the magnitude of change in $\mathrm{pH}$ that was observed. Increases in heavy metal concentrations have also been reported, including an increase in lead concentration, with $1.4 \mathrm{pg} / \mathrm{L}$ in approximately 2000-year-old ice, as compared to 150 to $200 \mathrm{pg} / \mathrm{L}$ in modern arctic ice (Murozumi et al., 1969; Wolff and Peel, 1985, 1988). Candelone et al. $(1993,1994)$ and Boutron et al.
(1995) have also reported rises in cadmium (5 times), copper (3 times), lead (20 times), and zinc (5 times) on the basis of Greenland ice cores dating from approximately 1770 to the mid-1960s. The rise in trace metal concentrations recorded in the Greenland ice cores parallels the general increase in metal emissions, which resulted from the expansion of industrialization (Nriagu and Pacyna, 1988). However, since the 1980s, organolead concentrations have dropped because of bans on using alkylated lead additives in gasoline in the United States and other countries (Lobinski et al., 1993).

A major impediment in assessing the impacts of heavy metals and other trace elements on arctic ecosystems is the extremely low concentration (in the picogram-per-liter range) of most elements present in the precipitation. At such low concentrations, sample contamination becomes increasingly likely, and accurate analysis increasingly difficult (Herron et al., 1977; Mart, 1983; Wolff and Peel, 1985, 1988; Boutron et al., 1995). In this paper, we present results obtained using field-collection methods and analytical techniques specifically designed to reduce potential sources of trace element contamination and to increase the accuracy and precision of snow analyses. Results are reported for 16 soluble trace elements, 3 soluble major elements, and the total mercury from 11 arctic Alaskan sites, 2 in the Prudhoe Bay oil field and 9 in the Arctic National Wildlife Refuge (Arctic NWR). We also examine the geographical patterns and potential sources of these constituents in the samples. Results reported here are part of a comprehensive chemical analysis of Alaskan snow and moss (Hylocomium splendens) samples from the Prudhoe Bay area and the Arctic NWR; data for trace element concentrations in the insoluble material, nutrient concentrations, $\mathrm{pH}$, specific conductance, and concentration of trace organic compounds will be presented in a separate article.

The objectives of this part of the study were as follows: 1) to determine the concentration of soluble trace elements (soluble fraction only) and total mercury (soluble plus insoluble fractions) in annual snowfall deposited during the 1993-94 season because of atmospheric pollution in the Arctic NWR; 2) to determine the contribution of contaminants caused by local sources in the Prudhoe Bay oil field; and 3 ) to provide baseline data using total annual snow accumulation as a record of atmospheric pollutants in case the Arctic NWR is opened for oil exploration and development. One of the questions examined is whether depositional processes are accelerated in the foothills and mountains (Wright and Dovland, 1978). We also investigate whether there are significant linear relationships between the concentrations of various trace elements in the snow and the distance to the coast, as reported by Landers et al. (1995) in northern Alaskan mosses and lichens, and whether there are any latitudinal or longitudinal gradients in trace element distribution.

\section{STUDY AREA}

The study area extended from the foothills of the Brooks Range to the Beaufort Sea coast and covered approximately 


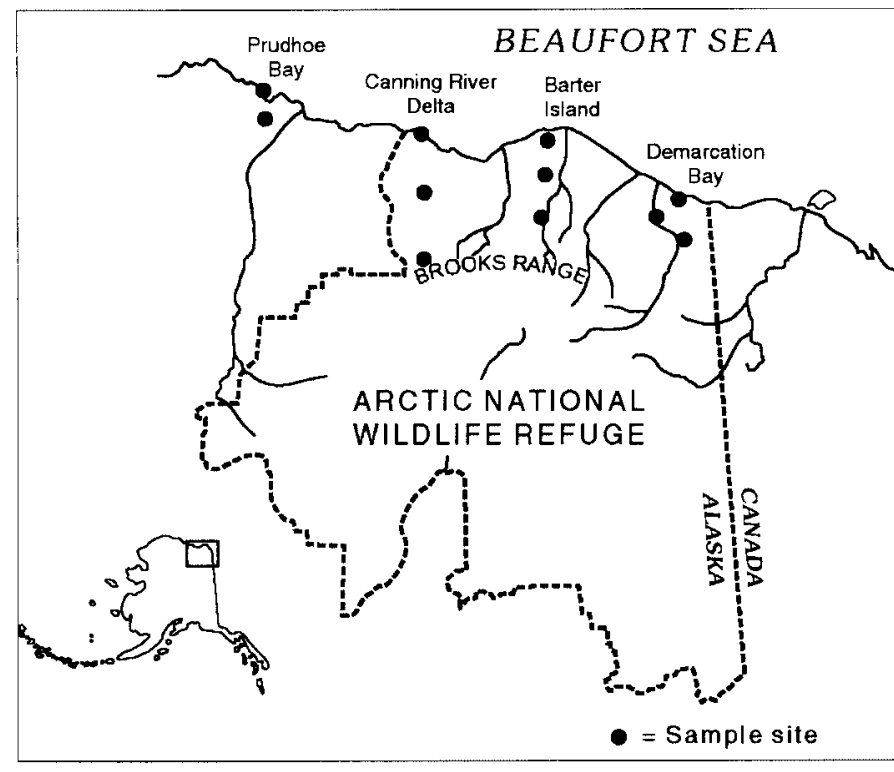

FIG. 1. Study area and snow core collection sites.

$28000 \mathrm{~km}^{2}$ in the central and eastern parts of the North Slope of Alaska (Fig. 1). Eleven sites were sampled along four approximately equally spaced longitudinal transects-one through Prudhoe Bay, one along the Canning River on the western edge of the Arctic NWR, one originating near Barter Island in the central part of the Refuge, and one through Demarcation Bay on the eastern edge of the Refuge, near the Canadian border. Three sample sites were selected along each of the four longitudes, one within $1 \mathrm{~km}$ of the coast, one $10-30 \mathrm{~km}$ farther inland, and one $22-70 \mathrm{~km}$ south of the coast in the foothills of the Brooks Range. The foothill sample for the Prudhoe Bay transect was not collected because of logistical constraints. Sites were selected in reference to the coast and the foothills, with the aim of having the inland site approximately midway between the foothill and coastal sites. This sampling pattern was designed to evaluate potential differences in trace element deposition among coastal, inland, and foothill sites, to identify any east-west trends in trace element deposition, and to quantify trace element contributions from Prudhoe Bay oil field activities.

\section{METHODS}

\section{Field Procedures}

Samples were collected in early May 1994, to obtain the cumulative seasonal snowfall immediately prior to the spring melt. On the basis of previous polar snow studies, care was taken to avoid possible sources of contamination. Snow samples generally were collected over frozen lakes, ponds, or rivers to avoid contamination from soil and vegetation. Prudhoe Bay sites were accessed by road, and samples were taken 300-500 m from any roads in snowfields overlying frozen lakes. The remaining nine Arctic NWR sites were accessed in a helicopter, which landed approximately $300 \mathrm{~m}$ downwind of the preselected sample site. Accurate site locations were determined using a geographical positioning system. Site locations and ancillary information on the snow samples collected are listed in Table 1.

Tools used in the excavation and collection of the snow samples were selected to be noncontaminating and were thoroughly cleaned before use. The aluminum shovel, used to excavate the snow as well as to collect the hydrocarbon samples, was rinsed with HPLC-grade hexane, then HPLCgrade acetone, and wrapped in clean aluminum foil, dull side in. Large and small polyethylene scoops were used to obtain a clean side-wall at each excavation site and to collect the snow samples. The scoops were precleaned with dilute hydrochloric acid, Millipore Milli-Q deionized water, and then sealed in polyethylene bags.

Mercury sample containers were wide-mouth, $2 \mathrm{~L}$, screw cap, perfluoroalkyoxy-polymer (PFA Teflon) jars and lids. The bottles were precleaned at Frontier Geosciences, Seattle, Washington, by heating in Baker reagent grade 4N hydrochloric acid for $40 \mathrm{~h}$ at $75^{\circ} \mathrm{C}$ in a clean room oven, and then thoroughly rinsed with doubly distilled water (DDW) having a confirmed low mercury concentration $(\leq 0.5 \mathrm{ng} / \mathrm{g})$. The sample jars then were filled with $0.5 \%$ (volume:volume) $\mathrm{HCl}$ in DDW, hermetically sealed, and double-bagged in polyethylene bags while inside a Class-100 clean station, prior to being shipped to the collection site.

Trace element snow samples were placed in precleaned, $33 \mathrm{~cm} \times 46 \mathrm{~cm}$ PFA bags. These bags were precleaned at the U.S. Geological Survey's (USGS) National Water Quality Laboratory, Arvada, Colorado, by leaching the inside and outside of each bag with $5 \% \mathrm{HNO}_{3}$ for 48 hours at $25^{\circ} \mathrm{C}$, thoroughly rinsed with doubly deionized water, air dried, and individually packaged inside two similarly precleaned polyethylene bags. All bags were cleaned and packaged inside a Class-100 clean room equipped with high-efficiency particulate (HEPA) filters.

Tyvex outerwear and talc-free latex gloves were worn by both individuals while sampling in the field. Surgical masks were worn when wind velocities were less than about $8 \mathrm{~km}$ per hour. Thereafter, a "clean hands/dirty hands" technique was used, with one person opening storage containers and outer bags of equipment and sample containers, while the designated "clean hands" person opened the precleaned sample containers and used the precleaned sampling tools to collect the snow samples. In the case of the Demarcation Bay sites, one person served both functions, donning new gloves as needed to do "clean" work.

At each site, an aluminum shovel was used to dig a trench to expose a vertical snow wall. After the trench was completed, a precleaned rectangular polyethylene scoop was used to trim a $5-10 \mathrm{~cm}$ layer away from the trench wall to remove snow that had contacted the aluminum shovel. Snow was then collected from the excavated face of the wall, by removing a rectangular vertical core with the polyethylene scoop. A single mercury snow-core sample and three trace element snow-core samples were collected at each site. Immediately after each mercury sample was taken, the respective sample 
TABLE 1. Description of snow sampling sites visited in May 1994.

\begin{tabular}{|c|c|c|c|c|c|c|}
\hline Site & $\begin{array}{l}\text { Date of } \\
\text { collection }\end{array}$ & Latitude & Longitude & $\begin{array}{c}\text { Snow } \\
\text { depth } \\
(\mathrm{cm})\end{array}$ & $\begin{array}{l}\text { Snow } \\
\text { density } \\
(\%)\end{array}$ & $\begin{array}{c}\text { Water } \\
\text { conten } \\
(\mathrm{mL})\end{array}$ \\
\hline \multicolumn{7}{|c|}{ Prudhoe Bay } \\
\hline Coastal & 2 May & $70^{\circ} 22^{\prime} \mathrm{N}$ & $148^{\circ} 30^{\prime} \mathrm{W}$ & 10.1 & 11 & 1.3 \\
\hline Inland & 2 May & $70^{\circ} 13^{\prime} \mathrm{N}$ & $148^{\circ} 27^{\prime} \mathrm{W}$ & 24.9 & 40 & 10.2 \\
\hline \multicolumn{7}{|c|}{ Canning River } \\
\hline Coastal & 3 May & $70^{\circ} 08^{\prime} \mathrm{N}$ & $145^{\circ} 47^{\prime} \mathrm{W}$ & 56.1 & 40 & 22.4 \\
\hline Inland & 3 May & $69^{\circ} 46^{\prime} \mathrm{N}$ & $145^{\circ} 44^{\prime} \mathrm{W}$ & 51.3 & 40 & 22.4 \\
\hline Foothill & 3 May & $69^{\circ} 23^{\prime} \mathrm{N}$ & $145^{\circ} 46^{\prime} \mathrm{W}$ & 61.5 & 29 & 17.8 \\
\hline \multicolumn{7}{|c|}{ Barter Island } \\
\hline Coastal & 5 May & $70^{\circ} 04^{\prime} \mathrm{N}$ & $143^{\circ} 37^{\prime} \mathrm{W}$ & 15.0 & 28 & 4.1 \\
\hline Inland & 5 May & $69^{\circ} 53^{\prime} \mathrm{N}$ & $143^{\circ} 41^{\prime} \mathrm{W}$ & 19.8 & 33 & 6.6 \\
\hline Foothill & 5 May & $69^{\circ} 40^{\prime} \mathrm{N}$ & $143^{\circ} 48^{\prime} \mathrm{W}$ & 49.3 & 34 & 17.0 \\
\hline \multicolumn{7}{|c|}{ Demarcation Bay } \\
\hline Coastal & 6 May & $69^{\circ} 41^{\prime} \mathrm{N}$ & $141^{\circ} 30^{\prime} \mathrm{W}$ & 30.5 & 37 & 11.2 \\
\hline Inland & 6 May & $69^{\circ} 36^{\prime} \mathrm{N}$ & $141^{\circ} 52^{\prime} \mathrm{W}$ & 12.7 & 24 & 3.1 \\
\hline Foothill & 6 May & $69^{\circ} 27^{\prime} \mathrm{N}$ & $141^{\circ} 28^{\prime} \mathrm{W}$ & 20.3 & 20 & 4.0 \\
\hline
\end{tabular}

jar was securely capped, sealed in the original precleaned bag, and then sealed inside the second precleaned bag. A field blank (dilute acid with a known low mercury concentration) and a spiked sample were also collected for mercury analysis. Mercury samples were collected first because of the low concentrations expected and the greater likelihood of inadvertent contamination. Unfortunately, freezing temperatures affected closure of mercury sample jars, resulting in several lids that were less than hand-tight on receipt at the analytical services laboratory.

Snow samples for trace element constituents were collected after the mercury samples. An inverted plastic trash can with a cut-out bottom was used to suspend each PFA sample bag and to hold it open during snow collection. The bag was secured with a bungie cord covered with Tygon tubing. After the Teflon bag was filled, it was immediately sealed using interlocking precleaned plastic strips and returned to its original precleaned outer bag.

Samples were kept frozen after field collection, shipped frozen to Fairbanks, Alaska, by air courier in insulated boxes, and stored at approximately $-10^{\circ} \mathrm{C}$. Immediately after the sampling was completed, mercury samples were deep-frozen to $-50^{\circ} \mathrm{C}$ and shipped to Frontier Geosciences for analysis the following day. Trace element samples were stored at $-10^{\circ} \mathrm{C}$ for several weeks before being deep-frozen to $-50^{\circ} \mathrm{C}$ and packed with dry ice in insulated boxes. Samples were then shipped to the National Water Quality Laboratory for trace element analysis.

Ancillary measurements included snow depth and snow density, except for the Demarcation Bay sites, where snow density was not measured because of logistical constraints. The snow density at these locations was estimated, however, on the basis of an algorithm developed by regressing the snow density and corresponding water volumes in the $2 \mathrm{~L}$ mercury containers from other locations $\left(r^{2}=0.91, \mathrm{df}=7\right)$.

Several difficulties were encountered during sampling. At the Canning River foothill site, deep snow precluded reaching the $300 \mathrm{~m}$ minimum distance from the helicopter; therefore, samples were collected at a distance of approximately
$100 \mathrm{~m}$. Snow at this site included obvious pollen and small insects. The analytical laboratory also reported woody debris in several samples. At the Canning River coastal site, researchers encountered underlying tundra rather than lake ice, and additional attempts to locate the pond failed. Cobbles were encountered at the Barter Island and the Demarcation Bay foothill sites. In both these cases, the lowest snow layer was not sampled to avoid possible contamination with vegetation or debris.

\section{Laboratory Procedures and Data Quality Assessment}

Mercury: Mercury was determined by Frontier Geosciences on whole, unfiltered snowmelt samples using picogram-level methods (Bloom and Crecilius, 1983; Bloom and Fitzgerald, 1988; Liang and Bloom, 1993). Immediately on arrival at the laboratory, $1.0 \mathrm{~mL}$ of $0.2 \mathrm{~N}$ bromine monochloride in $12 \mathrm{~N}$ hydrochloric acid was added to each frozen sample, and the sample was allowed to thaw and oxidize overnight. Snowmelt volumes for the samples varied from $320-470 \mathrm{~mL}$. The following day, $100 \mu \mathrm{L}$ of $20 \%$ hydroxylamine hydrochloride solution was added to the mercury sample before transferring it into a bubbler containing $0.3 \mathrm{~mL}$ of a stannous chloride solution. The elemental mercury produced by the reducing agents was purged from the solution using nitrogen gas for 20 minutes and concentrated on gold-coated quartz sand as an amalgam. The mercury was released from the amalgam using heat and determined by cold vapor-atomic fluorescence spectrometry (CV-AFS). Calibration standards were prepared by serial dilutions of National Institute of Standards and Technology's (NIST) mercury spectrometric standard solution (NIST-3133). The method detection limit for mercury, determined in reagent blanks using the procedure described by the U.S. Environmental Protection Agency (1994), was $0.00001 \mu \mathrm{g} / \mathrm{L}$.

Duplicates were analyzed on the field blank, field spike, and two snow samples. The mean relative percent difference (RPD) for all duplicates was $12 \%$, indicating acceptable precision. Two replicate samples collected at one site were also analyzed. The RPD for these snow samples was $36 \%$, indicating some within-site variability. The mean recovery of $0.008 \mu \mathrm{g} / \mathrm{L}$ mercury spiked into three different snowmelt samples was $94 \pm 8 \%$. Average mercury concentration in laboratory reagent blanks $(\mathrm{n}=2)$ measured $0.00005 \mu \mathrm{g} / \mathrm{L}$, indicating negligible reagent contamination. Acidified water in the precleaned PFA containers averaged $0.00042 \mu \mathrm{g} / \mathrm{L}$ mercury $(\mathrm{n}=4)$ prior to shipment and sample collection. Mercury concentrations in an aliquot of the same acidified water stock solution after pouring it into a second precleaned PFA container at the Barter Island foothill site were 0.00229 and $0.00224 \mu \mathrm{g} / \mathrm{L}$ in duplicate analyses, indicating possible field contamination at approximately $0.00184 \mu \mathrm{g} / \mathrm{L}$.

Other Trace Elements: Soluble trace elements were determined at the National Water Quality Laboratory. All snow samples were processed inside a Class-100 clean room. During the analyses, the samples were exposed to the 
TRACE ELEMENTS AND MERCURY IN SNOW • 205

environment only while inside a laminar-flow clean bench. Both the clean room and the clean bench used HEPA-type filtering systems. Upon reaching the laboratory, the snow was weighed and allowed to melt at room temperature inside its PFA bag. Between 1360 and $1850 \mathrm{~mL}$ of the snowmelt from each snow core was gravity filtered through a disposable, precleaned polypropylene filter funnel having a $47 \mathrm{~mm}$ diameter, $0.40 \mu \mathrm{m}$ pore size, Nuclepore polycarbonate membrane. A new filter funnel and membrane were used for each snowmelt sample. After filtration, the filtrate was acidified to $1 \%$ (volume:volume) with ultrapure nitric acid, resulting in a $\mathrm{pH}$ of approximately 1 . Filtration of the snowmelt removed particulate material greater than $0.40 \mu \mathrm{m}$; colloidal material less than $0.40 \mu \mathrm{m}$ was retained in the filtrate. Trace elements associated with the colloidal material were quantified either by dissolution by the nitric acid or through entrainment of the acid-insoluble material into the plasma excitation source of the spectrometric technique.

Prior to elemental analysis, sample filtrates were concentrated by 10 times $(10 \times)$ and 50 times $(50 \times)$, using subboiling evaporation, to increase the accuracy and precision of the snow sample analyses by effectively reducing the limits of detection. The subboiling evaporation process used a custom-built graphite heating block maintained at a temperature of about $85^{\circ} \mathrm{C}$. The heating block was designed to evaporate 12 samples simultaneously using $250 \mathrm{~mL}$ polypropylene evaporation vessels. The heating block was covered with a polyethylene enclosure to minimize the possibility of contamination while the samples were evaporated within a polyethylene fume hood inside the clean room. Less than $72 \mathrm{~h}$ were needed to evaporate twelve $1 \mathrm{~L}$ samples to $20 \mathrm{~mL}$. The original snowmelt filtrates $(1 \times)$, original snowmelt filtrates concentrated by $10 \times$, and original snowmelt filtrates concentrated by $50 \times$ were each analyzed three times.

Calcium, iron, silicon, and sodium were determined in the $1 \times$ filtrates only by inductively coupled plasma-optical emission spectrometry (ICP-OES) using a nitrogen-purged optical path Thermo Jarrel-Ash Model 61E spectrometer according to previously described methods (Garbarino and Taylor, 1979; Fishman and Friedman, 1989). Aluminum, antimony, arsenic, barium, beryllium, cadmium, chromium, cobalt, copper, lead, magnesium, manganese, molybdenum, nickel, silver, strontium, thallium, uranium, vanadium, and zinc were determined by inductively coupled plasma-mass spectrometry (ICP-MS) using a VG Elemental PlasmaQuad PQ-1. Detailed information on the instrumental method is provided in Taylor and Garbarino (1991), Faires (1993), and Garbarino and Taylor (1994). Method detection limits for ICP-OES and ICP-MS are listed in Table 2.

During the analysis of the $1 \times, 10 \times$, and $50 \times$ samples, either USGS standard reference water samples T121, T123, T125, and P17 or NIST trace elements in water standard 1643B were analyzed three times to verify the accuracy of the instrument calibration. Experimental means for all trace element standards were within $1.5 \sigma$ of the certified most probable values. All coefficients of variation, used to
TABLE 2. Method detection limits for this study.

\begin{tabular}{lclc}
\hline \hline Element $^{1}$ & MDL $^{2}(\mu \mathrm{g} / \mathrm{L})$ & Element & MDL $(\mu \mathrm{g} / \mathrm{L})$ \\
\hline Aluminum, ICP-MS & 0.3 & Manganese, ICP-MS & 0.1 \\
Antimony, ICP-MS & 0.2 & Mercury, CV-AFS & 0.00001 \\
Arsenic, ICP-MS & 0.6 & Molybdenum, ICP-MS & 0.2 \\
Barium, ICP-MS & 0.2 & Nickel, ICP-MS & 0.5 \\
Beryllium, ICP-MS & 0.2 & Silicon (SiO $)$, ICP-OES & 20 \\
Cadmium, ICP-MS & 0.3 & Silver, ICP-MS & 0.2 \\
Calcium, ICP-OES & 2 & Sodium, ICP-OES & 20 \\
Chromium, ICP-MS & 0.2 & Strontium, ICP-MS & 0.1 \\
Cobalt, ICP-MS & 0.2 & Thallium, ICP-MS & 0.1 \\
Copper, ICP-MS & 0.2 & Uranium, ICP-MS & 0.2 \\
Iron, ICP-OES & 3 & Vanadium, ICP-MS & 0.1 \\
Lead, ICP-MS & 0.3 & Zinc, ICP-MS & 0.5 \\
Magnesium, ICP-MS & 0.1 & & \\
\hline
\end{tabular}

${ }^{1} \mathrm{ICP}-\mathrm{MS}$, inductively coupled plasma-mass spectrometry; ICPOES, inductively coupled plasma-optical emission spectrometry; CV-AFS, cold vapor-atomic fluorescence spectrometry.

${ }^{2}$ Method detection limit (MDL) calculated using the U.S. Environmental Protection Agency (1994) method.

estimate the precision relative to the average measured concentration, were less than $20 \%$.

A certified standard reference water sample and a multielement standard were diluted 1:10 or 1:50 prior to being evaporated with each batch of snowmelt samples to evaluate the accuracy of the evaporative process. USGS standard reference water sample T123 has most probable values based on interlaboratory analyses for all the trace elements determined in this study except thallium and uranium. The multielement standard contained every trace element except silver, strontium, and elements determined by ICP-OES. Recoveries for calcium, iron, magnesium, and sodium were not determined. A process blank (doubly deionized water acidified to $1 \%$, volume:volume, with ultrapure nitric acid) also was evaporated with each batch to evaluate potential sources of laboratory contamination. The quality control data obtained using T123, the multielement standard, and the process blank are listed in Table 3.

For the 10x evaporations, all trace element concentrations in the process blanks were less than the effective method detection limits (a factor of 10 lower than the concentrations listed in Table 2) except for aluminum, cobalt, and zinc. The mean concentration for aluminum $(0.1 \mu \mathrm{g} / \mathrm{L})$ was insignificant compared to the lowest measured aluminum concentration in the snow samples. However, the mean process blank concentrations for cobalt $(0.08 \mu \mathrm{g} / \mathrm{L})$ and zinc $(0.2 \mu \mathrm{g} / \mathrm{L})$ are potentially significant with respect to the reported lowest concentrations measured in the snow samples. At 50×, all trace element concentrations in the process blanks were less than the effective detection limits (a factor of 50 lower than the concentrations listed in Table 2 ) except for aluminum $(0.04 \mu \mathrm{g} / \mathrm{L})$, chromium $(0.005 \mu \mathrm{g} / \mathrm{L})$, cobalt $(0.02 \mu \mathrm{g} / \mathrm{L})$, manganese $(0.009 \mu \mathrm{g} / \mathrm{L})$, and zinc $(0.05 \mu \mathrm{g} / \mathrm{L})$. Only the mean process blank concentrations for chromium and cobalt are potentially significant.

Mean recoveries for T123 10× evaporations were within $1 \sigma$ of the most probable value for all elements except for 
TABLE 3. Trace element quality control results, in micrograms per liter, from a process blank, a diluted certified standard reference, and a diluted synthetic multielement standard evaporated with each batch of snow samples, where $10 \times$ and $50 \times$ means and standard deviations $(1 \sigma)$ are based on four replicate analyses.

\begin{tabular}{|c|c|c|c|c|c|c|c|c|}
\hline \multirow[b]{2}{*}{ Element } & \multicolumn{2}{|c|}{ Process blank ${ }^{1}$} & \multicolumn{3}{|c|}{ SRWS T123² } & \multicolumn{3}{|c|}{ Multielement standard ${ }^{3}$} \\
\hline & $10 \times$ & $50 \times$ & Most probable value & $10 \times$ & $50 \times$ & Theoretical value & $10 \times$ & $50 \times$ \\
\hline Aluminum & 0.1 & 0.04 & $10 \pm 10$ & $8.0 \pm 0.4$ & $10 \pm 1$ & $5.5 \pm 0.1$ & $6 \pm 1$ & $8 \pm 4$ \\
\hline Antimony & $<0.02$ & $<0.004$ & $7 \pm 2$ & $6.3 \pm 0.9$ & $7 \pm 1$ & $6.17 \pm 0.02$ & $5.9 \pm 0.4$ & $5.6 \pm 0.4$ \\
\hline Arsenic & $<0.06$ & $<0.01$ & $20 \pm 2$ & $19 \pm 2$ & $20 \pm 1$ & $4.93 \pm 0.08$ & $4.5 \pm 0.4$ & $4.6 \pm 0.6$ \\
\hline Barium & $<0.02$ & $<0.004$ & $7.6 \pm 0.9$ & $7.1 \pm 0.5$ & $7.8 \pm 0.6$ & $5.0 \pm 0.1$ & $4.8 \pm 0.3$ & $5.1 \pm 0.5$ \\
\hline Beryllium & $<0.02$ & $<0.004$ & $8.1 \pm 0.8$ & $7.5 \pm 0.6$ & $7.9 \pm 0.4$ & $4.72 \pm 0.07$ & $4.7 \pm 0.2$ & $4.4 \pm 0.5$ \\
\hline Cadmium & $<0.03$ & $<0.006$ & $5.9 \pm 0.9$ & $5.3 \pm 0.4$ & $6.0 \pm 0.2$ & $4.9 \pm 0.5$ & $4.9 \pm 0.5$ & $5.0 \pm 0.5$ \\
\hline Chromium & $<0.02$ & 0.005 & $11 \pm 1$ & $9.3 \pm 0.7$ & $9 \pm 1$ & $4.94 \pm 0.02$ & $4.8 \pm 0.4$ & $5 \pm 2$ \\
\hline Cobalt & 0.08 & 0.02 & $5.3 \pm 0.8$ & $5.7 \pm 0.6$ & $7 \pm 2$ & $5.23 \pm 0.07$ & $5.5 \pm 0.7$ & $7 \pm 2$ \\
\hline Copper & $<0.02$ & $<0.004$ & $10 \pm 1$ & $9.6 \pm 0.3$ & $10.7 \pm 0.8$ & $4.8 \pm 0.2$ & $4.7 \pm 0.5$ & $4.9 \pm 0.4$ \\
\hline Lead & $<0.03$ & $<0.006$ & $10 \pm 2$ & $9.7 \pm 0.7$ & $10.3 \pm 0.7$ & $5.09 \pm 0.06$ & $4.8 \pm 0.4$ & $5.0 \pm 0.3$ \\
\hline Manganese & 0.02 & 0.009 & $14 \pm 1$ & $12.7 \pm 0.9$ & $13.5 \pm 0.9$ & $4.9 \pm 0.2$ & $5.0 \pm 0.4$ & $5.3 \pm 0.4$ \\
\hline Molybdenum & $<0.02$ & $<0.004$ & $9 \pm 1$ & $9 \pm 1$ & $9.8 \pm 0.9$ & $5.53 \pm 0.09$ & $5.0 \pm 0.5$ & $5.4 \pm 0.4$ \\
\hline Nickel & $<0.05$ & $<0.01$ & $4 \pm 1$ & $4.2 \pm 0.4$ & $5.1 \pm 0.7$ & $4.7 \pm 0.3$ & $4.5 \pm 0.5$ & $5 \pm 1$ \\
\hline Silver & $<0.02$ & $<0.004$ & $1.4 \pm 0.6$ & $1.4 \pm 0.2$ & $1.3 \pm 0.2$ & $n a^{4}$ & - & - \\
\hline Strontium & $<0.01$ & $<0.002$ & $49 \pm 3$ & $46 \pm 3$ & $47 \pm 2$ & na & - & - \\
\hline Thallium & $<0.01$ & $<0.002$ & na & - & - & $5.4 \pm 0.4$ & $4.9 \pm 0.4$ & $5.1 \pm 0.4$ \\
\hline Uranium & $<0.02$ & $<0.004$ & na & - & - & $5.16 \pm 0.07$ & $5.0 \pm 0.4$ & $4.5 \pm 0.8$ \\
\hline Vanadium & $<0.01$ & $<0.002$ & $4 \pm 1$ & $4.0 \pm 0.7$ & $3.7 \pm 0.3$ & $5.5 \pm 0.4$ & $4.8 \pm 0.4$ & $5.0 \pm 0.6$ \\
\hline Zinc & 0.2 & 0.05 & $6 \pm 4$ & $6.7 \pm 0.7$ & $10 \pm 2$ & $5.1 \pm 0.3$ & $6.1 \pm 0.4$ & $9 \pm 2$ \\
\hline
\end{tabular}

${ }^{1}$ The mean elemental concentration based on four replicates of the reagent blank following $10 \times$ and $50 \times$ evaporations. Less than $(<)$ values were below the stated effective method detection limit (from Table 2).

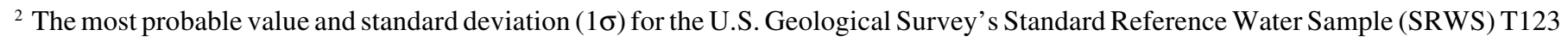
based on round-robin results using multiple analytical methods.

${ }^{3}$ The elemental mean and standard deviation $(1 \sigma)$ for the multielement mixed standard based on four replicates.

${ }^{4}$ Not available (na) because the standard did not contain the element.

aluminum and chromium, and 50× evaporations were all within $1 \sigma$ except for chromium, cobalt, and zinc. Slightly elevated concentrations for aluminum and zinc, presumably caused by laboratory contamination, are indicated in the 50x results. Recoveries for the multielement standard were also acceptable with the exception of aluminum and zinc.

The field blank collected at the Barter Island foothill site was concentrated by $50 \times$ and analyzed by ICP-MS. Analyte concentrations in the field blank were either less than the method detection limits or insignificant with respect to the concentration levels measured in the snowmelt from this site except for barium $(2.9 \mu \mathrm{g} / \mathrm{L})$, copper $(0.18 \mu \mathrm{g} / \mathrm{L})$, and zinc $(6.6 \mu \mathrm{g} / \mathrm{L})$. Trace element and mercury concentrations measured in the field blank collected at the Barter Island foothill site were not subtracted from the analytical results from any collection site, including the Barter Island foothill site. However, these data provide an estimate of possible snow-sample contamination that may aid in interpreting results at the Barter Island site. The field blank data may also be applicable, to a much lesser extent, to the other sampling sites.

The nonparametric One-sample Sign Test was used to determine whether there was a significant difference between the $10 \times$ and $50 \times$ trace element results at the $95 \%$ confidence level. Results of the test suggest that there is significant difference between the $10 \times$ and $50 \times$ results for aluminum, arsenic, cobalt, silver, thallium, and vanadium. Since the concentrations of copper, manganese, molybdenum, strontium, and zinc were present at detectable levels in the $1 \times$ snowmelt samples, the $1 \times, 10 \times$, and $50 \times$ results could be compared using the Kruskal-Wallis Test. This test indicated that any differences in the results for these elements were insignificant at the $95 \%$ confidence level.

On the basis of measured concentrations in the snowmelt samples in relation to the effective limits of detection, the accuracy and precision of the quality control results, and the average level of contamination in the process blanks, we report arsenic, chromium, molybdenum, strontium, vanadium, and zinc concentrations obtained from the $10 \times$ evaporations. Similarly, aluminum, antimony, barium, cadmium, copper, lead, manganese, nickel, and uranium concentrations were based on the $50 \times$ evaporation results. Cobalt concentrations are not reported because of the relatively high concentrations measured in the $10 \times$ and $50 \times$ process blanks; most beryllium, silicon (as $\left.\mathrm{SiO}_{2}\right)$, silver, and thallium concentrations were less than the effective detection limits and are not reported.

\section{RESULTS AND DISCUSSION}

\section{Trace Element Concentrations, Probable Sources, and Interrelationships}

Measurable trace element concentrations in snow at the 11 sample locations are listed in Table 4. Product-moment correlation coefficient matrices compare trace element 
TABLE 4. Mean trace element concentrations, in micrograms per liter, measured in snow collected in May 1994 from Prudhoe Bay and the Arctic National Wildlife Refuge, Alaska, where < indicates that the result was less than the effective method detection limit after concentration and the standard deviation $(1 \sigma)$ is for three replicate samples per site unless otherwise stated.

\begin{tabular}{|c|c|c|c|c|c|}
\hline Site & Aluminum & Antimony & Arsenic & Barium & Cadmium \\
\hline \multicolumn{6}{|l|}{ Prudhoe Bay } \\
\hline Coastal & $62 \pm 13$ & $0.015 \pm 0.001$ & $0.084 \pm 0.004$ & $74 \pm 9$ & $0.012 \pm 0.004$ \\
\hline Inland & $3.4 \pm 0.5$ & $0.060 \pm 0.008$ & $<0.06$ & $8.1 \pm 0.3$ & $0.12+0.02$ \\
\hline \multicolumn{6}{|c|}{ Canning River } \\
\hline Coastal & $3.5 \pm 0.7$ & $0.009 \pm 0.001$ & $<0.06$ & $2.0 \pm 0.2$ & $0.014 \pm 0.001$ \\
\hline Inland & $3.6 \pm 0.9$ & $<0.004$ & $<0.06$ & $0.68 \pm 0.04$ & $0.009 \pm 0.002$ \\
\hline Foothill & $4.1 \pm 1.6$ & $<0.004$ & $<0.06$ & $0.31 \pm 0.05$ & $0.006 \pm 0.001$ \\
\hline \multicolumn{6}{|c|}{ Barter Island } \\
\hline Coastal & $3.4 \pm 0.4$ & $<0.004$ & $<0.06$ & $0.62 \pm 0.05$ & $0.010 \pm 0.001$ \\
\hline Inland & $4.7 \pm 0.9$ & $0.004 \pm 0.001$ & $<0.06$ & $0.7 \pm 0.2$ & $0.010 \pm 0.001$ \\
\hline Foothill & $3.4 \pm 1.0$ & $0.008 \pm 0.004$ & $0.062 \pm 0.006$ & $0.46 \pm 0.02$ & $0.010 \pm 0.001$ \\
\hline \multicolumn{6}{|c|}{ Demarcation Bay } \\
\hline Coastal & $3.2 \pm 0.5$ & $0.006 \pm 0.001$ & $<0.06$ & $0.62 \pm 0.09$ & $0.008 \pm 0.001$ \\
\hline Inland & $4.4 \pm 0.3$ & $<0.004$ & $<0.06$ & $0.6 \pm 0.4$ & $0.007 \pm 0.001$ \\
\hline Foothill $^{1}$ & $7 \pm 6$ & $<0.004$ & $<0.06$ & $0.38 \pm 0.15$ & $0.008 \pm 0.001$ \\
\hline Site & Calcium & Chromium & Copper & Iron & Lead \\
\hline \multicolumn{6}{|l|}{ Prudhoe Bay } \\
\hline Coastal & $7700 \pm 900$ & $0.09 \pm 0.06$ & $0.19 \pm 0.04$ & $76 \pm 4$ & $0.109 \pm 0.019$ \\
\hline Inland & $940 \pm 80$ & $0.072 \pm 0.009$ & $0.42 \pm 0.05$ & $7 \pm 3$ & $1.4 \pm 0.4$ \\
\hline \multicolumn{6}{|c|}{ Canning River } \\
\hline Coastal & $440 \pm 40$ & $0.024 \pm 0.013$ & $0.122 \pm 0.001$ & $3.7 \pm 0.5$ & $0.20 \pm 0.03$ \\
\hline Inland & $420 \pm 130$ & $<0.02$ & $0.059 \pm 0.011$ & $5 \pm 3$ & $0.08 \pm 0.03$ \\
\hline Foothill & $1000 \pm 400$ & $<0.02$ & $0.047 \pm 0.002$ & $7 \pm 6$ & $0.060 \pm 0.012$ \\
\hline \multicolumn{6}{|c|}{ Barter Island } \\
\hline Coastal & $600 \pm 100$ & $0.027 \pm 0.017$ & $0.110 \pm 0.006$ & $9 \pm 2$ & $0.088 \pm 0.013$ \\
\hline Inland & $700 \pm 300$ & $<0.02$ & $0.10 \pm 0.02$ & $8 \pm 3$ & $0.08 \pm 0.02$ \\
\hline Foothill & $580 \pm 80$ & $<0.02$ & $0.072 \pm 0.003$ & $5.8 \pm 1.4$ & $0.068 \pm 0.010$ \\
\hline \multicolumn{6}{|c|}{ Demarcation Bay } \\
\hline Coastal & $1370 \pm 120$ & $0.02 \pm 0.03$ & $0.069 \pm 0.007$ & $<3$ & $0.09 \pm 0.02$ \\
\hline Inland & $1300 \pm 1400$ & $0.02 \pm 0.05$ & $0.044 \pm 0.011$ & $5 \pm 4$ & $0.08 \pm 0.03$ \\
\hline Foothill $^{1}$ & 270 & 0.057 & $0.076 \pm 0.008$ & $<3$ & $0.08 \pm 0.03$ \\
\hline Site & Magnesium & Manganese & Mercury $^{2}$ & Molybdenum & Nickel \\
\hline \multicolumn{6}{|l|}{ Prudhoe Bay } \\
\hline Coastal & $520 \pm 130$ & $14 \pm 2$ & 0.08360 & $0.034 \pm 0.007$ & $0.276 \pm 0.016$ \\
\hline Inland & $220 \pm 50$ & $1.85 \pm 0.08$ & 0.00122 & $0.043 \pm 0.012$ & $0.101 \pm 0.014$ \\
\hline \multicolumn{6}{|c|}{ Canning River } \\
\hline Coastal & $730 \pm 80$ & $1.4 \pm 0.4$ & 0.00750 & $<0.02$ & $0.065 \pm 0.014$ \\
\hline Inland & $90 \pm 18$ & $2.5 \pm 0.8$ & 0.00412 & $<0.02$ & $0.052 \pm 0.007$ \\
\hline Foothill & $59 \pm 11$ & $1.87 \pm 0.17$ & 0.00145 & $0.028 \pm 0.003$ & $0.033 \pm 0.004$ \\
\hline \multicolumn{6}{|c|}{ Barter Island } \\
\hline Coastal & $660 \pm 30$ & $2.7 \pm 0.4$ & 0.00420 & $<0.02$ & $0.070 \pm 0.004$ \\
\hline Inland & $600 \pm 300$ & $6 \pm 3$ & 0.00719 & $0.020 \pm 0.006$ & $0.068 \pm 0.019$ \\
\hline Foothill & $169 \pm 19$ & $4.6 \pm 0.7$ & 0.00649 & $<0.02$ & $0.065 \pm 0.004$ \\
\hline \multicolumn{6}{|c|}{ Demarcation Bay } \\
\hline Coastal & $3200 \pm 400$ & $2.9 \pm 0.6$ & 0.00286 & $0.025 \pm 0.015$ & $0.066 \pm 0.005$ \\
\hline Inland & $200 \pm 200$ & $1.2 \pm 0.5$ & 0.00309 & $<0.02$ & $0.049 \pm 0.010$ \\
\hline Foothill $^{1}$ & $39 \pm 13$ & $1.3 \pm 0.5$ & 0.00098 & $<0.02$ & $0.052 \pm 0.001$ \\
\hline Site & Sodium & Strontium & Uranium & Vanadium & Zinc \\
\hline \multicolumn{6}{|l|}{ Prudhoe Bay } \\
\hline Coastal & $2400 \pm 500$ & $12.9 \pm 1.8$ & $0.029 \pm 0.009$ & $0.16 \pm 0.08$ & $0.94 \pm 0.14$ \\
\hline Inland & $1200 \pm 300$ & $2.8 \pm 0.4$ & $<0.004$ & $0.020 \pm 0.009$ & $5.2 \pm 0.4$ \\
\hline \multicolumn{6}{|c|}{ Canning River } \\
\hline Coastal & $4200 \pm 400$ & $4.4 \pm 0.4$ & $<0.004$ & $0.06 \pm 0.04$ & $0.93 \pm 0.14$ \\
\hline Inland & $180 \pm 60$ & $1.0 \pm 0.3$ & $<0.004$ & $0.012 \pm 0.012$ & $2.66 \pm 1.9$ \\
\hline Foothill & $44 \pm 7$ & $1.8 \pm 0.2$ & $0.005 \pm 0.001$ & $<0.01$ & $0.56 \pm 0.13$ \\
\hline Barter Islan & & & & & \\
\hline Coastal & $4290 \pm 100$ & $3.9 \pm 0.4$ & $0.005 \pm 0.001$ & $<0.01$ & $1.6 \pm 0.3$ \\
\hline Inland & $4000 \pm 2000$ & $4 \pm 2$ & $0.005 \pm 0.002$ & $0.032 \pm 0.017$ & $1.74 \pm 0.12$ \\
\hline Foothill & $211 \pm 16$ & $2.8 \pm 0.2$ & $0.005 \pm 0.001$ & $0.04 \pm 0.02$ & $1.1 \pm 0.3$ \\
\hline Demarcation & & & & & \\
\hline Coastal & $10500 \pm 1000$ & $16 \pm 3$ & $0.006 \pm 0.002$ & $<0.01$ & $1.10 \pm 0.08$ \\
\hline Inland & $110 \pm 30$ & $4 \pm 5$ & $0.010 \pm 0.015$ & $0.03 \pm 0.03$ & $0.37 \pm 0.13$ \\
\hline Foothill $^{1}$ & 18 & 0.68 & $<0.004$ & $<0.01$ & $0.55 \pm 0.10$ \\
\hline
\end{tabular}

${ }^{1}$ Only duplicate sample results are averaged for this foothill site; single measurements are reported for arsenic, calcium, chromium, iron, molybdenum, sodium, strontium, uranium, and vanadium.

${ }^{2}$ A single mercury sample was collected at each site. 
TABLE 5. Product-moment correlation coefficient matrix for all Arctic National Wildlife Refuge and Prudhoe Bay sampling sites.

\begin{tabular}{|c|c|c|c|c|c|c|c|c|c|c|c|c|c|c|c|c|c|c|c|c|c|}
\hline Element $^{1}$ & & Al & $\mathbf{S b}$ & As & $\mathbf{B a}$ & Cd & $\mathrm{Ca}$ & $\mathrm{Cr}$ & $\mathrm{Cu}$ & $\mathbf{F e}$ & $\mathbf{P b}$ & Mg & Mn & Hg & Mo & $\mathbf{N i}$ & $\mathbf{N a}$ & $\mathbf{S r}$ & $\mathbf{U}$ & $\mathbf{V}$ & $\mathbf{Z n}$ \\
\hline Aluminum & Al & 1 & & & & & & & & & & & & & & & & & & & \\
\hline Antimony & Sb & 0.07 & 1 & & & & & & & & & & & & & & & & & & \\
\hline Arsenic & As & 0.63 & 0.16 & 1 & & & & & & & & & & & & & & & & & \\
\hline Barium & $\mathbf{B a}$ & 0.96 & 0.17 & 0.65 & 1 & & & & & & & & & & & & & & & & \\
\hline Cadmium & Cd & -0.09 & 0.93 & -0.01 & 0.02 & 1 & & & & & & & & & & & & & & & \\
\hline Calcium & $\mathrm{Ca}$ & 0.96 & 0.09 & 0.61 & 0.96 & -0.07 & 1 & & & & & & & & & & & & & & \\
\hline Chromium & $\mathrm{Cr}$ & 0.47 & 0.46 & 0.32 & 0.60 & 0.37 & 0.50 & 1 & & & & & & & & & & & & & \\
\hline Copper & $\mathbf{C u}$ & 0.22 & 0.95 & 0.20 & 0.31 & 0.88 & 0.22 & 0.52 & 1 & & & & & & & & & & & & \\
\hline Iron & $\mathbf{F e}$ & 0.98 & 0.09 & 0.62 & 0.97 & -0.05 & 0.95 & 0.48 & 0.24 & 1 & & & & & & & & & & & \\
\hline Lead & $\mathbf{P b}$ & -0.09 & 0.96 & 0.02 & 0.01 & 0.93 & -0.08 & 0.37 & 0.92 & -0.07 & 1 & & & & & & & & & & \\
\hline Magnesium & Mg & -0.05 & -0.12 & -0.03 & -0.05 & -0.14 & 0.05 & 0.02 & -0.11 & -0.08 & -0.13 & 1 & & & & & & & & & \\
\hline Manganese & Mn & 0.82 & -0.01 & 0.55 & 0.85 & -0.14 & 0.82 & 0.39 & 0.13 & 0.86 & -0.17 & 0.03 & 1 & & & & & & & & \\
\hline Mercury $^{2}$ & Hg & 0.99 & 0.06 & 0.75 & 0.99 & -0.11 & 0.98 & 0.60 & 0.20 & 0.99 & -0.12 & -0.02 & 0.92 & 1 & & & & & & & \\
\hline Molybdenum & Mo & 0.30 & 0.56 & 0.07 & 0.39 & 0.59 & 0.36 & 0.37 & 0.58 & 0.37 & 0.52 & 0.07 & 0.36 & 0.36 & 1 & & & & & & \\
\hline Nickel & $\mathrm{Ni}$ & 0.95 & 0.27 & 0.64 & 0.96 & 0.10 & 0.93 & 0.58 & 0.43 & 0.95 & 0.11 & 0.01 & 0.86 & 0.97 & 0.41 & 1 & & & & & \\
\hline Sodium & $\mathrm{Na}$ & -0.03 & -0.11 & -0.07 & -0.03 & -0.12 & 0.04 & 0.05 & -0.04 & -0.05 & -0.12 & 0.95 & 0.09 & 0.02 & 0.08 & 0.06 & 1 & & & & \\
\hline Strontium & $\mathrm{Sr}$ & 0.47 & -0.04 & 0.36 & 0.49 & -0.14 & 0.60 & 0.32 & 0.02 & 0.44 & -0.15 & 0.80 & 0.48 & 0.53 & 0.25 & 0.52 & 0.74 & 1 & & & \\
\hline Uranium & $\mathbf{U}$ & 0.83 & -0.03 & 0.54 & 0.81 & -0.18 & 0.92 & 0.41 & 0.09 & 0.80 & -0.18 & 0.02 & 0.69 & 0.95 & 0.18 & 0.78 & 0.00 & 0.59 & 1 & & \\
\hline Vanadium & $\mathbf{V}$ & 0.96 & 0.15 & 0.72 & 0.93 & -0.01 & 0.92 & 0.48 & 0.31 & 0.93 & -0.01 & -0.01 & 0.77 & 0.97 & 0.28 & 0.94 & 0.03 & 0.48 & 0.78 & 1 & \\
\hline Zinc & Zn & -0.13 & 0.79 & -0.05 & -0.04 & 0.80 & -0.14 & 0.24 & 0.76 & -0.08 & 0.79 & -0.15 & -0.10 & -0.13 & 0.37 & 0.06 & -0.11 & -0.21 & $-0.24-$ & -0.10 & 1 \\
\hline
\end{tabular}

${ }^{1}$ Coefficients greater than or equal to 0.95 are listed in boldface type.

${ }^{2}$ All product-moment correlation coefficients involving mercury were determined using the mean concentration for each trace element and the single mercury concentration for each site.

TABLE 6. Product-moment correlation coefficient matrix for all Arctic National Wildlife Refuge sampling sites only.

\begin{tabular}{|c|c|c|c|c|c|c|c|c|c|c|c|c|c|c|c|c|c|c|c|c|c|}
\hline Element $^{1}$ & & Al & Sb & As & $\mathbf{B a}$ & Cd & $\mathrm{Ca}$ & $\mathrm{Cr}$ & $\mathbf{C u}$ & $\mathbf{F e}$ & $\mathbf{P b}$ & Mg & Mn & Hg & Mo & $\mathbf{N i}$ & $\mathbf{N a}$ & $\mathbf{S r}$ & $\mathbf{U}$ & $\mathbf{V}$ & Zn \\
\hline Aluminum & Al & 1 & & & & & & & & & & & & & & & & & & & \\
\hline Antimony & Sb & 0.02 & 1 & & & & & & & & & & & & & & & & & & \\
\hline Arsenic & As & 0.08 & 0.67 & 1 & & & & & & & & & & & & & & & & & \\
\hline Barium & $\mathbf{B a}$ & -0.04 & 0.59 & 0.41 & 1 & & & & & & & & & & & & & & & & \\
\hline Cadmium & Cd & -0.08 & 0.60 & 0.43 & 0.75 & 1 & & & & & & & & & & & & & & & \\
\hline Calcium & $\mathbf{C a}$ & 0.18 & -0.04 & -0.10 & -0.03 & -0.45 & 1 & & & & & & & & & & & & & & \\
\hline Chromium & $\mathrm{Cr}$ & -0.31 & 0.00 & -0.10 & 0.11 & 0.20 & -0.18 & 1 & & & & & & & & & & & & & \\
\hline Copper & $\mathbf{C u}$ & -0.15 & 0.38 & 0.11 & 0.67 & 0.72 & -0.22 & 0.17 & 1 & & & & & & & & & & & & \\
\hline Iron & $\mathrm{Fe}$ & 0.60 & -0.15 & -0.11 & -0.23 & -0.01 & -0.20 & -0.26 & 0.03 & 1 & & & & & & & & & & & \\
\hline Lead & $\mathbf{P b}$ & 0.02 & 0.50 & 0.38 & 0.81 & 0.75 & -0.32 & 0.09 & 0.59 & 0.00 & 1 & & & & & & & & & & \\
\hline Magnesium & Mg & -0.18 & 0.22 & 0.00 & 0.11 & 0.02 & 0.38 & 0.18 & 0.17 & -0.30 & 0.14 & 1 & & & & & & & & & \\
\hline Manganese & Mn & 0.18 & 0.09 & -0.01 & -0.12 & 0.06 & -0.01 & -0.12 & 0.29 & 0.16 & -0.30 & 0.10 & 1 & & & & & & & & \\
\hline Mercury $^{2}$ & Hg & -0.46 & 0.73 & 0.71 & 0.63 & 0.82 & -0.30 & -0.34 & 0.63 & 0.39 & 0.51 & -0.01 & 0.58 & 1 & & & & & & & \\
\hline Molybdenum & Mo & 0.18 & -0.26 & -0.31 & -0.29 & -0.25 & 0.24 & -0.17 & -0.18 & 0.25 & -0.26 & 0.25 & 0.31 & -0.16 & 1 & & & & & & \\
\hline Nickel & $\mathbf{N i}$ & -0.10 & 0.38 & 0.10 & 0.36 & 0.50 & 0.06 & 0.23 & 0.71 & -0.12 & 0.23 & 0.39 & 0.57 & 0.66 & -0.06 & 1 & & & & & \\
\hline Sodium & $\mathbf{N a}$ & -0.16 & 0.24 & -0.06 & 0.26 & 0.19 & 0.26 & 0.22 & 0.43 & -0.20 & 0.27 & 0.95 & 0.19 & 0.15 & 0.25 & 0.53 & 1 & & & & \\
\hline Strontium & $\mathrm{Sr}$ & -0.12 & 0.25 & 0.07 & 0.13 & -0.05 & 0.62 & 0.15 & 0.12 & -0.36 & 0.05 & 0.94 & 0.08 & -0.02 & 0.23 & 0.41 & 0.86 & 1 & & & \\
\hline Uranium & $\mathbf{U}$ & 0.17 & -0.01 & 0.02 & 0.05 & -0.29 & 0.87 & -0.13 & -0.08 & -0.18 & -0.28 & 0.09 & 0.01 & -0.05 & -0.05 & 0.16 & 0.01 & 0.40 & 1 & & \\
\hline Vanadium & $\mathbf{V}$ & 0.03 & 0.83 & 0.53 & 0.88 & 0.78 & -0.09 & 0.05 & 0.52 & -0.22 & 0.80 & 0.12 & -0.09 & 0.68 & -0.24 & 0.35 & 0.21 & 0.13 & -0.05 & 1 & \\
\hline Zinc & Zn & 0.02 & -0.07 & 0.00 & -0.01 & 0.03 & -0.29 & -0.16 & 0.21 & 0.33 & 0.03 & -0.05 & 0.26 & 0.37 & -0.17 & 0.20 & 0.02 & -0.14 & -0.20 & -0.16 & 1 \\
\hline
\end{tabular}

${ }^{1}$ Coefficients greater than or equal to 0.95 are listed in boldface type.

${ }^{2}$ All product-moment correlation coefficients involving mercury were determined using the mean concentration for each trace element and the single mercury concentration for each site.

concentrations between all Arctic NWR and Prudhoe Bay samples (Table 5), and between the Arctic NWR samples only (Table 6). Different element associations are revealed by the two matrices. Stronger correlation coefficients (coefficients greater than or equal to 0.95 , boldface in Tables 5 and 6 ) are generally shown among certain trace element pairs when Prudhoe Bay samples are included, which suggests discrete oil-field point sources. The results for the two Prudhoe Bay sites differ from the other sites and from one another. Snow at the Prudhoe Bay coastal site was enriched in aluminum, arsenic, barium, calcium, chromium, iron, manganese, mercury, nickel, uranium, and vanadium when compared to all other sites, including the inland Prudhoe Bay site (Table 4).

The mercury concentration is also of particular concern, since the concentration exceeds federal and state waterquality standards for the protection of aquatic life. The high correlation of mercury with aluminum, barium, calcium, and other drilling fluid-related elements means that mercury could be of widespread concern in the oil field. However, our mercury results were based on a single sample at each site; 


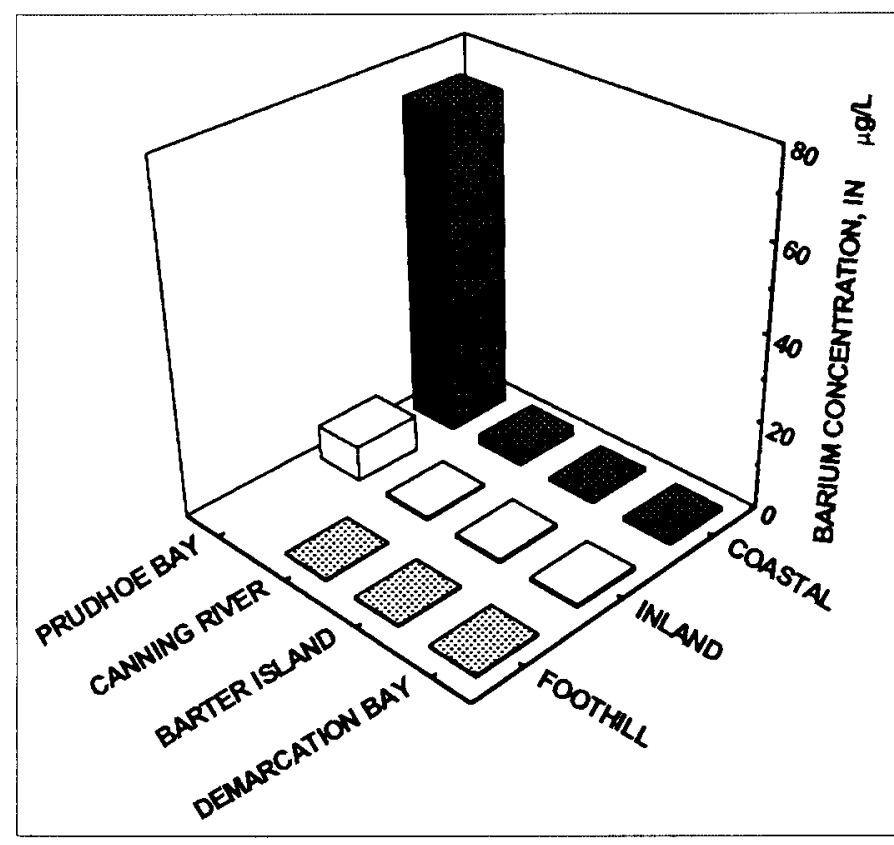

FIG. 2. Geographical distribution of barium.

additional sampling is needed before any conclusions are drawn. Barium concentrations illustrate the geographical pattern observed for this suite of trace elements (Fig. 2). In contrast, the inland Prudhoe Bay site was uniquely elevated in antimony, cadmium, copper, lead, and zinc compared to all other sites, as shown by the lead data in Figure 3 . These results suggest two distinct point sources of atmospheric contaminants within the oil field, a source or sources associated with oil and gas at the Prudhoe Bay coastal site, and one or more sources associated with incineration at the Prudhoe Bay inland site.

The coastal Prudhoe Bay site is immediately northwest of ARCO's Central Compression Plant and Central Gas Facility, the largest gas-handling facility in the world, with daily production of about 200 million $\mathrm{m}^{3}$ of natural gas (Harry Engel, ARCO Alaska, pers. comm. 1996). The main function of the facility is natural gas liquid (NGL) production. During upset conditions at the facility, natural gas or NGL, or both, may be flared as a safety precaution to prevent excess gas and NGL buildup in the plant, resulting in air emissions. Nickel and vanadium are the most abundant trace elements in petroleum, sometimes reaching thousands of parts per million (Yen, 1975; Clark and Brown, 1977). Both trace elements are also enriched in atmospheric aerosols resulting from petroleum combustion (Lowenthal and Rahn, 1985; Nriagu and Pacyna, 1988). Aluminum, calcium, iron, and manganese are also enriched at this site relative to the other sites and are typically regarded as having crustal origin (Lowenthal and Rahn, 1985; Heidam, 1986). These elements, as well as uranium, probably become enriched at this particular site as a result of the entrainment of drilling formation components into petroleum products. Aluminum, barium, and chromium are also recognized indicators of drilling muds (Chow and Snyder, 1980; Gettlesen and Laird, 1980; Kalil, 1980; Liss et

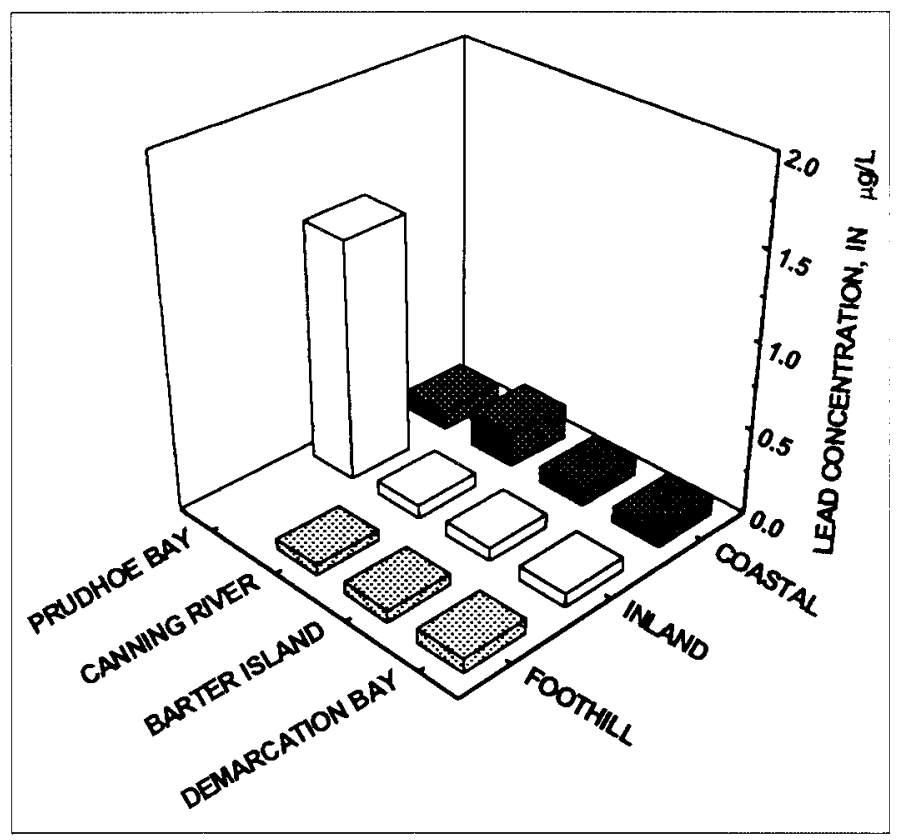

FIG. 3. Geographical distribution of lead.

al., 1980), including the drilling muds used at Prudhoe Bay (West and Snyder-Conn, 1987; Woodward et al., 1988). We hypothesize that the metals enriched at the coastal Prudhoe Bay site relative to other sites resulted from natural gas or NGL, or both, emissions containing metals that were crustally derived, drilling mud-derived, and naturally occurring in the natural gas or NGL, or both.

The inland Prudhoe Bay site was enriched in trace elements, including antimony, cadmium, lead, and zinc, which are frequently associated with refuse incinerators (Greenberg et al., 1978a, b; Nriagu and Pacyna, 1988). The site was on the southeastern side of Lake Coleen, downhill from a municipal and industrial solid waste incineration facility. During the winter of 1993-94, the facility experienced problems associated with the secondary burner system that controls volatile and ash particulate emissions (Alfred K. Bohn, Alaska Department of Environmental Conservation, Anchorage, pers. comm. 1996). These problems most likely resulted in the incomplete combustion of solid wastes. Also, lead-acid batteries were being improperly incinerated at this facility during the same period. Other intermittent point sources of trace elements at the inland site may include gasoline exhaust and several diesel electric generators from nearby service facilities that provide backup to electrical services.

Another suite of elements, including sodium, magnesium, and strontium, illustrates a third geographical pattern (Fig. 4), a trend of concentrations that decrease with distance inland. These elements appear to be derived from sea salts, an association also observed in previous studies (Boutron and Lorius, 1979; Gjessing, 1984; Shaw, 1991b).

Cluster analysis graphically demonstrates the relationships among trace elements in snow from all nine Arctic NWR sampling sites as well as the relationships between the 


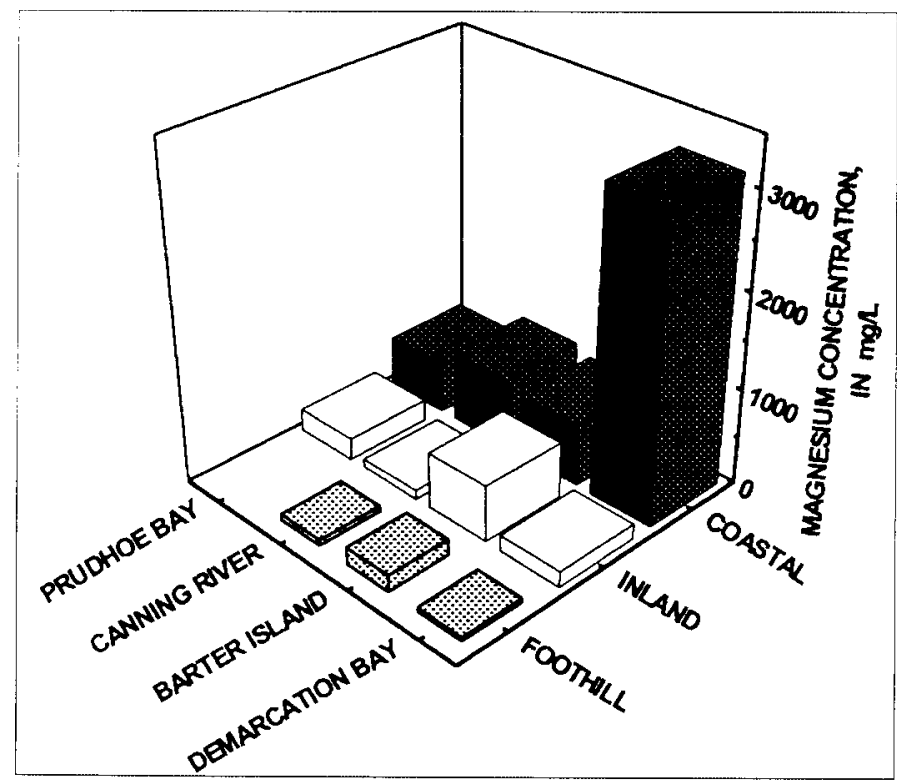

FIG. 4. Geographical distribution of magnesium.

Arctic NWR results and the results from the two Prudhoe Bay sites. When Prudhoe Bay sites are included, results of the analysis (Fig. 5a) identify three major clusters having similarity coefficients equal to 0.95 or greater. Elements associated with Prudhoe Bay drilling operations and natural gas emissions (aluminum, barium, calcium, iron, nickel, and vanadium), sea salts (magnesium and sodium), and Prudhoe Bay incinerator operations (antimony, cadmium, copper, and lead) are clearly defined as individual clusters. Mercury results were not included in the cluster analysis, because only a single sample was collected for each site; however, the correlation matrix in Table 5 suggests that mercury is associated with drilling sources at Prudhoe Bay. When Prudhoe Bay sites are excluded from the data set, only one cluster having a similarity coefficient greater than 0.95 is indicated (Fig. 5b). This cluster, having magnesium, sodium, and strontium, is most likely related to sea salts.

\section{Comparison of Trace Element Concentrations with Previously Published Results}

Table 7 compares selected trace element concentrations measured in snow at Arctic NWR sites from our study to trace element concentrations in snow collected during different annual periods from northern Alaska, Greenland, Antarctica, and the eastern Arctic Ocean. Our results for cadmium, copper, and lead are remarkably similar to those of several previous studies in Greenland, and are consistent with deposition resulting from widespread arctic atmospheric contamination. Except for manganese, trace element concentrations are generally only two to three times those of Antarctica, indicating that northeastern Alaskan snow remains pristine despite much greater concentrations of trace elements in Arctic than in Antarctic atmospheric samples.

The trace element concentrations detected in this study were generally less than those reported by Weiss et al. (1978)
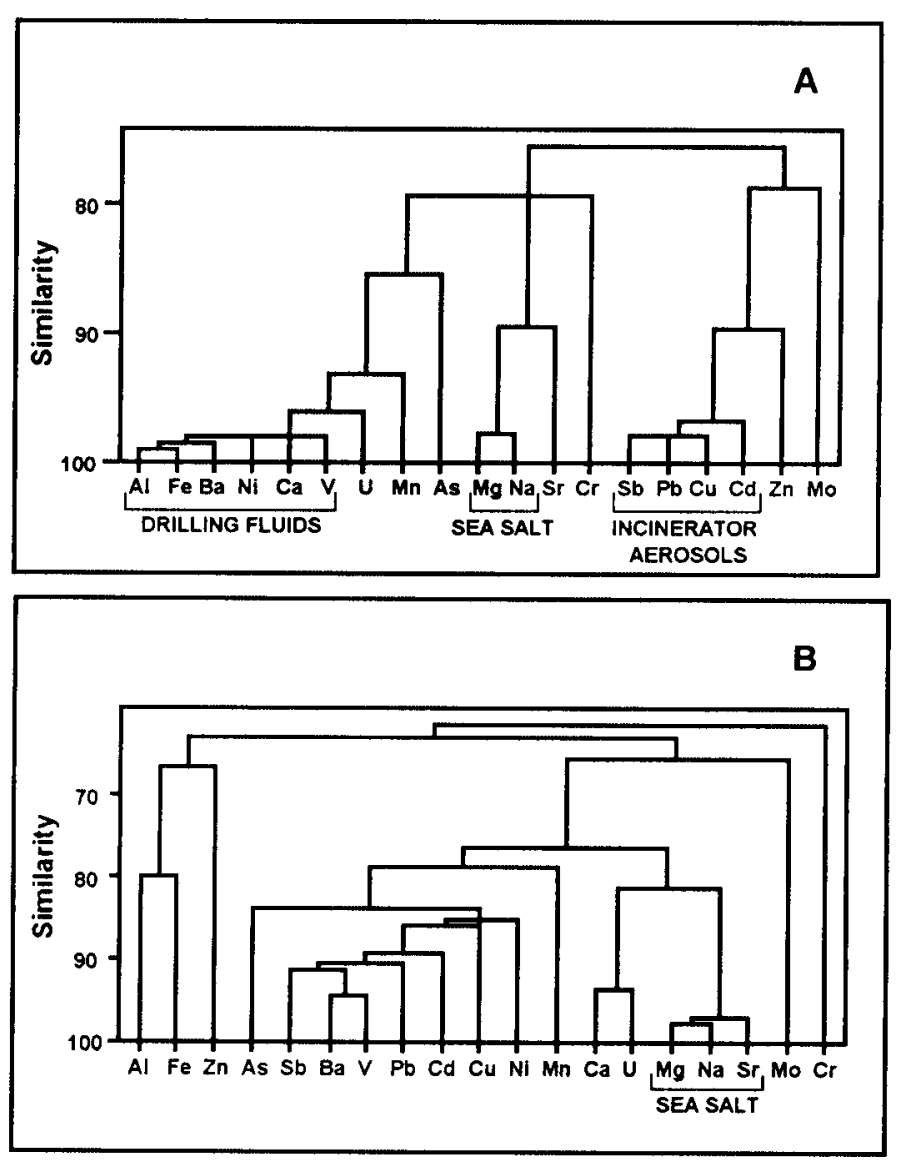

FIG. 5. Cluster diagrams showing elemental relationships for A) Arctic NWR and Prudhoe Bay data, and B) Arctic NWR without Prudhoe Bay data.

for sites inland from Barrow, Alaska, and west of our study area. These Barrow sites were closer to potential air pollution sources from Asia. It is also possible that the earlier studies entailed some incidental contamination since ultraclean procedures have improved since 1983. Increased concentrations in some of the other studies could also be the result of lack of filtration. Snowmelt from our samples sometimes contained woody debris, pollen, and insects; if not removed through filtration, these impurities conceivably could have increased trace element concentrations. Mart's (1983) results were obtained over sea ice, where greater nucleation on salt particles, more blowing of snow, and other processes (e.g., sublimation or freeze exclusion of trace elements from underlying ice) could have altered trace element concentrations. In fact, wind-driven snow redistribution, sublimation, and individual snow events also may have influenced trace element concentrations measured in this study. However, the extent of any bias from these mechanisms is unknown.

\section{Geographical Trends in Trace Element Concentrations}

Within the Arctic NWR, no significant east-west (longitudinal) trends were observed in the data, and there was no obvious influence of the Prudhoe Bay oil field atmospheric contaminants. This result is consistent with the predominant easterly and northeasterly wind regime on the North Slope of 
TABLE 7. Selected trace element concentrations, in micrograms per liter, measured in snow from various locations.

\begin{tabular}{|c|c|c|c|c|c|c|c|c|c|c|c|}
\hline Study & Location & Date & Aluminum & Cadmium & Copper & Lead & Manganese & Mercury & Nickel & Vanadium & Zinc \\
\hline This study & Alaska Arctic NWR & 1993-94 & 4 & 0.009 & 0.08 & 0.09 & 2.8 & 0.00421 & 0.058 & 0.023 & 1.2 \\
\hline Boutron and Lorius, 1979 & Antarctica & $1971-74$ & 1.14 & 0.019 & 0.062 & 0.041 & 0.018 & $\mathrm{nd}^{1}$ & nd & nd & 0.047 \\
\hline Davidson et al., 1985 & Greenland & 1983 & nd & 0.0085 & 0.092 & 0.129 & nd & nd & nd & nd & nd \\
\hline Wolff and Peel, 1988 & Greenland & $1983-84$ & 17.5 & 0.00074 & 0.0062 & 0.028 & nd & nd & nd & nd & 0.027 \\
\hline Mart, 1983 & Eastern Arctic Ocean & $1979-80$ & nd & 0.005 & 0.101 & 0.187 & nd & nd & 0.196 & nd & nd \\
\hline Weiss et al., 1975 & Greenland & 1975 & nd & 0.639 & nd & nd & nd & nd & nd & nd & 1.05 \\
\hline Weiss et al., 1978 & Northern Alaska & 1974 & 40 & 0.07 & nd & nd & 0.99 & $0.008^{2}$ & nd & 0.110 & 1.12 \\
\hline Herron et al., 1977 & Greenland & $1971-73$ & 10.67 & 0.008 & nd & 0.144 & 0.139 & nd & nd & 0.016 & 0.224 \\
\hline Murozumi et al., 1969 & Greenland & $1964-65$ & nd & nd & nd & 0.200 & nd & nd & nd & nd & nd \\
\hline
\end{tabular}

${ }^{1}$ nd $=$ not determined.

${ }^{2}$ Average of three measured concentrations and four concentrations that were less than the method detection limit of $0.005 \mu \mathrm{g} / \mathrm{L}$; for these latter values, $0.0025 \mu \mathrm{g} / \mathrm{L}$ was substituted.

TABLE 8. Data for freshwater and snow for selected mean trace element concentrations, in micrograms per liter, measured in the Arctic National Wildlife Refuge (Arctic NWR), Alaska, where < indicates that the mean concentration is less than the method detection limit or the snow-to-freshwater ratio is less than the stated value and $\mathrm{n}$ indicates the number of samples used to determine the mean.

\begin{tabular}{|c|c|c|c|c|c|c|c|c|c|c|c|}
\hline & Aluminum & Barium & Cadmium & Chromium & Copper & Iron & Manganese & Nickel & Lead & Vanadium & Zinc \\
\hline Arctic NWR fresh-water, ${ }^{1}$ mean, $\mathrm{n}=108$ & $<50$ & 7 & $<3$ & $<5$ & $<13$ & 410 & 14 & $<20$ & $<15$ & $<3$ & $6^{3}$ \\
\hline Arctic NWR snow, ${ }^{2}$ mean, $n=9$ & 4 & 0.7 & 0.009 & 0.026 & 0.08 & 6 & 2.8 & 0.058 & 0.09 & 0.023 & 1.2 \\
\hline Standard deviation at $1 \sigma$ & 1 & 0.5 & 0.002 & 0.012 & 0.03 & 2 & 1.8 & 0.012 & 0.04 & 0.018 & 0.7 \\
\hline Snow-to-freshwater ratio (percent) & $<8$ & 10 & $<0.3$ & $<0.3$ & $<0.6$ & 1 & 20 & $<0.3$ & $<0.6$ & $<0.8$ & 20 \\
\hline
\end{tabular}

${ }^{1}$ Data from Snyder-Conn and Lubinski, 1993, for mild nitric acid digestion of low-turbidity unfiltered freshwater.

2 This study.

${ }^{3}$ Only the 1988 geometric mean was used.

Alaska and the relatively distinct point sources of contamination in the Prudhoe Bay oil field.

Except for the elements associated with sea salts (magnesium, sodium, and strontium), no significant differences were identified among coastal, inland, and foothill sites in the Arctic NWR, indicating no significant, large-scale orographic effect. However, regression analysis of barium, cadmium, copper, lead, mercury, and vanadium on latitude revealed significant $(p<0.05)$ increases from south to north. Interestingly, these trends were not significantly related to distance from the coast, or to coastal, inland, or foothill location. Such trends may have been influenced by decreasing distances between the foothill, inland, and coastal sampling sites as longitudinal transects approached the Canadian border.

\section{Potential Impact of Trace Elements Associated with Snow on Arctic Alaskan Freshwater}

Arctic Alaskan freshwater may be particularly vulnerable to increased metal loading from atmospheric contamination since wetlands, ponds, and lakes receive all their water from precipitation and more than half of that water as snow (Miller et al., 1980; Liston, 1986). These systems are naturally oligotrophic (Alexander et al., 1980) and particularly low in trace element concentrations (Hobbie, 1973; Snyder-Conn and Lubinski, 1993). We compared the trace element concentrations in snow from the nine Arctic NWR sites with mean trace element concentrations in Arctic NWR ponds and lakes to evaluate the potential contribution of long-range atmospheric deposition of trace elements to aquatic ecosystems (see Table 8). Aluminum, barium, manganese, and zinc are the only elements present in snow at concentrations potentially significant to low-turbidity freshwater (snow-tofreshwater ratio greater than $8 \%$ ). It is therefore possible that cumulative loading of these metals could become significant. However, the global atmospheric contribution currently seems to be quite small, and the concentration of trace elements actually retained as soluble species in the water column is likely to be lower than the calculated snow-to-freshwater ratios because of active sorption processes. Even at Prudhoe Bay, most trace element concentrations in snow are unlikely to have serious impacts on water quality. However, increased loading of aluminum, barium, copper, lead, and zinc could result in significant increased loading from the adjacent point sources of contamination, depending on sorption and sedimentation processes.

\section{CONCLUSIONS}

Results of this study have shown that accumulated annual snowfall in the Arctic can be used as a record of atmospheric pollution, specifically as an integrator of soluble trace element contribution to aquatic and terrestrial ecosystems during the winter season (about nine months). Using productmoment correlation and cluster analysis, we identified two 
sources of trace elements in the Prudhoe Bay oil field-one related to oil and gas production and one linked to incineration of municipal solid waste. Even though trace element concentrations were found at measurable levels, all concentrations, with the possible exception of mercury, are less than established water quality criteria. Consequently, at 1993-94 levels of contamination in snow, toxic trace element contributions to the hydrologic system from these point sources seem to be small.

Trace element concentrations measured in snow samples collected from the Arctic National Wildlife Refuge provide benchmark chemical data that can be used in the future if the area is opened to oil-field development. Concentrations for many trace elements are similar to levels reported in snow from northern Alaska, Greenland, and the eastern Arctic Ocean. Most trace element concentrations are only a factor of two or three times greater than those of Antarctica, suggesting that snow in the Refuge remains relatively uncontaminated and unaffected by global atmospheric pollutants. There were no detectable trace element contributions from Prudhoe Bay oil-field operations, probably because of the localized nature of Prudhoe Bay trace element sources and the Refuge's upwind location relative to the prevailing wind direction. No significant longitudinal trends in trace element concentrations were observed. Except for elements associated with sea salts, there were no significant differences in trace element concentrations in snow collected from coastal, inland, and foothill sites. Nevertheless, slight latitudinal increases from south to north were identified for barium, cadmium, copper, lead, mercury, and vanadium. The results indicate that the potential for significant impact on aquatic ecosystems in the Refuge from toxic trace elements associated with the 1993-94 snowfall was minor.

\section{ACKNOWLEDGEMENTS}

This study was funded by the U.S. Fish and Wildlife Service. We thank Richard McCaffrey for his assistance in conducting field studies and Patrick Sousa, Ecological Services, Fairbanks, Howard E. Taylor, U.S. Geological Survey, and Glenn Shaw, Geophysical Institute, University of Alaska, Fairbanks, for their respective editorial and technical reviews of the manuscript. The use of brand, firm, and trade names in this article is for identification purposes only and does not constitute endorsement by the U.S. Geological Survey.

\section{REFERENCES}

ALEXANDER, V., STANLEY, D.W., DALEY, R.J., and McROY, C.P. 1980. Primary producers. In: Hobbie, J.E., ed. Limnology of tundra ponds: Barrow, Alaska. US/IBP Synthesis Series 13. Stroudsburg, Pennsylvania: Dowden, Hutchinson \& Ross, Inc. 179-250.
BARRIE, L.A. 1986. Arctic air chemistry: An overview. In: Stonehouse, B., ed. Arctic air pollution. Cambridge, England: Cambridge University Press. 5-23.

BARRIE, L.A., and VET, R.J. 1984. The concentration and deposition of acidity, major ions and trace metals in the snowpack of the eastern Canadian shield during the winter of 1980-1981. Atmospheric Environment 18:1459-1469.

BARRIE, L.A., FISHER, D., and KOERNER, R.M. 1985. Twentieth century trends in arctic air pollution revealed by conductivity and acidity observations in snow and ice in the Canadian High Arctic. Atmospheric Environment 19:2055-2063.

BARRIE, L.A., HOFF, R.M., and DAGGUPATY, S.M. 1981. The influence of mid-latitudinal pollution sources on haze in the Canadian Arctic. Atmospheric Environment 15:1407-1419.

BIDLEMAN, T.F., PATTON, G.W., HINCKLEY, D.A., WALLA, M.D., COTHAM, W.E., and HARGRAVE, B.T. 1990. Chlorinated pesticides and polychlorinated biphenyls in the atmosphere of the Canadian Arctic. In: Kurtz, D.A., ed. Long range transport of pesticides. Chelsea, Michigan: Lewis Publishers, Inc. 347-372.

BLOOM, N.S., and CRECELIUS, E.A. 1983. Determination of mercury in seawater at sub-nanogram per liter levels. Marine Chemistry 14:49-59.

BLOOM, N.S., and FITZGERALD, W.F. 1988. Determination of volatile mercury species at the picogram level by low temperature gas chromatography with cold vapour atomic fluorescence detection. Analytica Chimica Acta 208:151-161.

BOUTRON, C.F., and LORIUS, C. 1979. Trace metals in Antarctic snows since 1914. Nature 277:551-554.

BOUTRON, C.F., CANDELONE, J.P., and HONG, S. 1995. Greenland snow and ice cores: Unique archives of large-scale pollution of the troposphere of the Northern Hemisphere by lead and other heavy metals. The Science of the Total Environment 160/161:233-241.

BOWES, G.W., and JONKEL, C.J. 1975. Presence and distribution of polychlorinated biphenyls (PCB) in arctic and subarctic marine food chains. Journal of the Fisheries Research Board of Canada 32:2111-2123.

BP EXPLORATION (ALASKA), INC. 1991. Project summary: Waste management facility: West Prudhoe Bay Operating Unit.

CANDELONE, J.P., HONG, S., and BOUTRON, C.F. 1993. The changing occurrence of $\mathrm{Pb}, \mathrm{Cd}, \mathrm{Zn}$, and $\mathrm{Cu}$ in Greenland snow from 1972 to 1965. In: Allan, R.J., and Nriagu, J.O., eds. Heavy metals in the environment. Norwich, U.K.: Page Brothers. 571574.

CANDELONE, J.P., HONG, S., and BOUTRON, C.F. 1994. An improved method for decontaminating polar snow or ice cores for heavy metals analysis. Analytica Chimica Acta 299:9-16.

CHOW, T.J., and SNYDER, C.B. 1980. Barium in the marine environments: A potential indicator of drilling contamination. In: Research on environmental fate and effects of drilling fluids and cuttings. Vol. 1, Symposium Proceedings, American Petroleum Institute, Lake Buena Vista, Florida, 21 - 24 January 1980. $723-736$.

CLARK, R.C., and BROWN, D.W., Jr. 1977. Petroleum properties and analysis in biotic and abiotic systems. In: Malins, D.C., ed. Effects of petroleum on arctic and subarctic marine environments 
and organisms. Vol. 1. Nature and fate of petroleum. New York: Academic Press. 1-89.

DAISEY, J.M., McCAFFREY, R.J., and GALLAGHER, R.A. 1981. Polycyclic aromatic hydrocarbons and total extractable particulate organic matter in arctic air. Atmospheric Environment 15:1353-1363.

DAVIDSON, C.I., HARRINGTON, J.R., STEPHENSON, M.J., SMALL, M.J., BOSCOE, F.P., and GANDLEY, R.E. 1989. Seasonal variations in sulfate, nitrate, and chloride in the Greenland Ice Sheet: Relation to atmospheric concentrations. Atmospheric Environment 23:2483-2493.

DAVIDSON, C.I., HONRATH, R.E., KADANE, J.B., TSAY, R.S., MAYEWSKI, P.A., LYONS, W.B., and HEIDAM, N.Z. 1987. The scavenging of atmospheric sulfate by Arctic snow. Atmospheric Environment 21:871-882.

DAVIDSON, C.I., SANTHANAM, S., FORTMANN, R.C., and OLSON, M.P. 1985. Atmospheric transport and deposition of trace elements onto the Greenland Ice Sheet. Atmospheric Environment 19:2065-2081.

FAIRES, L.M. 1993. Methods of analysis by the U.S. Geological Survey National Water Quality Laboratory-Determination of metals in water by inductively coupled plasma-mass spectrometry. U.S. Geological Survey Open-File Report 92-634.

FISHMAN, M.J., and FRIEDMAN, L.C., eds. 1989. Methods for the determination of inorganic substances in water and fluvial sediments. In: Techniques of Water-Resources Investigations of the United States Geological Survey. Book 5, Chapter A1. Denver, Colorado: U.S. Geological Survey.

FORD, J., LANDERS, D., KUGLER, D., LASORSA, B., ALLENGIL, S., CRECELIUS, E., and MARTINSON, J. 1995. Inorganic contaminants in Arctic Alaskan ecosystems: Long-range atmospheric transport or local sources? Science of the Total Environment 160/161:323-335.

GARBARINO, J.R., and TAYLOR, H.E. 1979. An inductivecoupled plasma atomic-emission spectrometric method for routine water quality testing. Applied Spectroscopy 33:220-226.

GARBARINO, J.R., and TAYLOR, H.E. 1994. Inductively coupled plasma-mass spectrometric method for the determination of dissolved trace elements in natural water. U.S. Geological Survey Open-File Report 94-358.

GETTLESEN, D.A., and LAIRD, C.E. 1980. Benthic barium levels in the vicinity of six drill sites in the Gulf of Mexico. In: Research on environmental fate and effects of drilling fluids and cuttings. Vol. 1, Symposium Proceedings, American Petroleum Institute, Lake Buena Vista, Florida, 21-24 January 1980. 739-785.

GJESSING, Y. 1984. Marine and non-marine contribution to the chemical composition of snow at the Riiser-Larsenisen Ice Shelf in Antarctica. Atmospheric Environment 18:825-830.

GOLDBERG, E.D. 1975. Synthetic organohalides in the sea. Proceedings of the Royal Society of London, Series B 189:277289.

1976. Rock volatility and aerosol composition. Nature 260:128-129.

GREENBERG, R.R., ZOLLER, W.H., and GORDON, G.E. 1978a. Composition and size distributions of particles released in refuse incineration. Environmental Science and Technology 12:566-573.
GREENBERG, R.R., GORDON, G.E., ZOLLER, W.H., JACKS, R.B., NEUENDORF, D.W., and YOST, K.J. 1978b. Composition of particles emitted from the Nicosia municipal incinerator. Environmental Science and Technology 12:1329-1332.

GREGOR, D.J. 1990. Deposition and accumulation of selected agricultural pesticides in Canadian Arctic snow. In: Kurtz, D.A., ed. Long range transport of pesticides. Chelsea, Michigan: Lewis Publishers, Inc. 373-386.

HEIDAM, N.Z. 1986. Trace metals in the Arctic aerosol. Advances in Environmental Science and Technology 17:267-293.

HEINTZENBERG, J. 1989. Arctic haze: Air pollution in the Arctic and Antarctic. Ambio 18:50-55.

HEINTZENBERG, J., and LARSSEN, S. 1983. $\mathrm{SO}_{2}$ and $\mathrm{SO}_{4}{ }^{2-}$ in the Arctic: Interpretation of observations at three Norwegian arctic-subarctic stations. Tellus 35B:255-265.

HERRON, M.M., LANGWAY, C.C., Jr., WEISS, H.V., and CRAGIN, J.H. 1977. Atmospheric trace metals and sulfates in the Greenland Ice Sheet. Geochimica et Cosmochimica Acta 41:915-920.

HOBBIE, J.E. 1973. Arctic limnology: A review. In: Britton, M.E., ed. Arctic Alaskan tundra. Arctic Institute of North America Technical Paper 25. 127-166.

IWATA, H., TANABE, S., SAKAI, N., and TATSUKAWA, R. 1993. Distribution of persistent organochlorines in the oceanic air and surface seawater and the role of ocean on their global transport and fate. Environmental Science and Technology 27:1080-1098.

JAFFE, D.A. 1991. Local sources of pollution in the Arctic from Prudhoe Bay to the Taz Peninsula. In: Sturges, W.T., ed. Pollution of the arctic atmosphere. New York: Elsevier Applied Science. 255-287.

JAFFE, D.A., and ZUKOWSKI, M.D. 1993. Nitrate deposition to the Alaskan snowpack. Atmospheric Environment 27A:29352941.

JAFFE, D.A., HONRATH, R.E., HERRING, J.A., LI, S.-M., and KAHL, J.D. 1991. Measurements of nitrogen oxides at Barrow, Alaska during spring: Evidence for regional and northern hemispheric sources of pollution. Journal of Geophysical Research 96(D4):7395-7405.

JUNGE, C.E. 1977. Processes responsible for trace content in precipitation. In: Isotopes and impurities in snow and ice. Proceedings of the International Union of Geodesy and Geophysics Symposium, Grenoble, August-September 1975. International Association of Hydrological Sciences Publication 118. 63-77.

KALIL, E.K. 1980. Chemical analysis of drill muds and discharge plumes. In: Research on environmental fate and effects of drilling fluids and cuttings. Vol. 1, Symposium Proceedings, American Petroleum Institute, Lake Buena Vista, Florida, 21 24 January 1980. 799-826.

KERR, R.A. 1979. Global pollution: Is the arctic haze actually industrial smog? Science 205(4403):290 - 293.

1981. Pollution of the Arctic confirmed. Science 212 (4498):1013-1014.

KHALIL, M.A.K., and RASMUSSEN, R.A. 1983. Gaseous tracers of arctic haze. Environmental Science and Technology 17:157163. 
KHALIL, M.A.K., and RASMUSSEN, R.A. 1984. Statistical analysis of trace gases in arctic haze. Geophysical Research Letters 11:437-440.

LANDERS, D.H., FORD, J., GUBALA, C., MONETTI, M., LASORSA, B.K., and MARTINSON, J. 1995. Mercury in vegetation and lake sediments from the U.S. Arctic. Water, Air and Soil Pollution 80:591-601.

LANDSBERGER, S., VERMETTE, V.G., STRUENKEL, D., HOPKE, P.K., CHENG, M.D., and BARRIE, L.A. 1992. Elemental source signatures of aerosols from the Canadian High Arctic. Environmental Pollution 75:181-187.

LI, S.-M. 1993. Water soluble organic constituents in arctic aerosols and snow pack. Geophysical Research Letters 20:45-48.

LIANG, L., and BLOOM, N.S. 1993. Determination of total mercury by single-stage gold amalgamation with cold vapour atomic spectrometric detection. Journal of Analytical Atomic Spectroscopy 8:591-594.

LISS, R.G., KNOX, F., WAYNE, D., and GILBERT, T.R. 1980. Availability of trace elements in drilling fluid to the marine environment. In: Research on environmental fate and effects of drilling fluids and cuttings. Vol. 1, Symposium Proceedings, American Petroleum Institute, Lake Buena Vista, Florida, 21 24 January 1980. 691-719.

LISTON, G. 1986. Seasonal snow cover of the foothills region of Alaska's arctic slope: A survey of properties and processes. M.S. Thesis, University of Alaska Fairbanks.

LOBINSKI, R., BOUTRON, C.F., CANDELONE, J.P., HONG, S., SZPUNAR-LOBINSKA, J., and ADAMS, F. 1993. The occurrence of organolead compounds in Greenland snow during the 1945-1989 period. In: Allan, R.J., and Nriagu, J.O., eds. Heavy metals in the environment. Norwich, U.K.: Page Brothers. $571-574$.

LOWENTHAL, D.H., and RAHN, K.A. 1985. Regional sources of pollution aerosol at Barrow, Alaska during winter 1979-80 as deduced from elemental tracers. Atmospheric Environment 19:2011-2024.

MART, L. 1983. Seasonal variations of $\mathrm{Cd}, \mathrm{Pb}, \mathrm{Cu}$ and Ni levels in snow from the eastern Arctic Ocean. Tellus 35B:131-141.

McNEELY, R., and GUMMER, W.D. 1984. A reconnaissance survey of the environmental chemistry in east-central Ellesmere Island, N.W.T. Arctic 37:210-223.

MILLER, M.C., PRENTKI, R.T., and BARSDATE, R.J. 1980. Physics. In: Hobbie, J.E., ed. Limnology of tundra ponds: Barrow, Alaska. US/IBP Synthesis Series 13. Stroudsburg, Pennsylvania: Dowden, Hutchinson \& Ross, Inc. 51-75.

MUROZUMI, M., CHOW, T.J., and PATTERSON, C.C. 1969. Chemical concentrations of pollutant lead aerosols, terrestrial dusts and sea-salts in Greenland and Antarctic snow strata. Geochimica et Cosmochimica Acta 33:1247-1294.

NRIAGU, J.O., and PACYNA, J.M. 1988. Quantitative assessment of worldwide contamination of air, water and soils with trace metals. Nature 333:134-139.

OEHME, M. 1982. Mass spectrometry and the analysis of ultratrace quantities of chlorinated compounds in arctic air. Trends in Analytical Chemistry 1:321-323.
RAHN, K.A. 1981. Atmospheric, riverine and oceanic sources of seven trace constituents to the Arctic Ocean. Atmospheric Environment 15:1507-1516.

RAHN, K.A., and LOWENTHAL, D.H. 1986. Who's polluting the Arctic? Why is it so important to know? An American perspective. In: Stonehouse, B., ed. Arctic air pollution. Cambridge, England: Cambridge University Press. 85-95.

RAHN, K.A., and McCAFFREY, R.J. 1979a. Long range transport of pollution aerosol to the Arctic: A problem without borders. In: Proceedings of the World Meteorological Organization Symposium on the long range transport of pollutants and its relation to general circulation including stratospheric/ tropospheric exchange processes. Sofia, Bulgaria, 1-5 October 1979. WMO No. 538. 25-35.

RAHN, K.A., and McCAFFREY, R.J. 1979b. Compositional differences between arctic aerosol and snow. Nature 280:479-480.

RAHN, K.A., and McCAFFREY, R.J. 1980. On the origin and transport of the winter arctic aerosol. Annals of the New York Academy of Science 338:486-503.

RAHN, K.A., BORYS, R.D., and SHAW, G.E. 1981. Asian dust over Alaska: Anatomy of an arctic haze episode. In: Péwé, T.L., ed. Desert dust: Origin, characteristics, and effect on man. Special Paper 186. Boulder, Colorado: Geological Society of America.

RASMUSSEN, R.A., and KHALIL, M.A.K. 1984. Gaseous bromine in the Arctic and arctic haze. Geophysical Research Letters 11:433-436.

RASMUSSEN, R.A., KHALIL, M.A.K., and FOX, R.J. 1983. Altitudinal and temporal variations in hydrocarbons and other gaseous tracers of arctic haze. Geophysical Research Letters 10:144-147.

SHAW, G.E. 1976. Comparison of Arctic and Antarctic haze. Antarctic Journal of the United States 11(3):151.

- 1982. Evidence for a central Eurasian source area of arctic haze in Alaska. Nature 299:815-818.

_. 1991a. Aerosol chemical components in Alaska air masses. 1. Aged pollution. Journal of Geophysical Research 96(D12): 22357-22368.

- 1991b. Aerosol chemical components in Alaska air masses. 2. Sea salt and marine product. Journal of Geophysical Research 96(D12):22369-22372.

SHAW, G.E., and STAMNES, K. 1980. Arctic haze: Perturbation of the polar radiation budget. Annals of the New York Academy of Science 338:533-540.

SLEMR, F., and LANGER, E. 1992. Increase in global atmospheric concentrations of mercury inferred from measurements over the Atlantic Ocean. Nature 355:434-437.

SNYDER-CONN, E., and LUBINSKI, M. 1993. Contaminant and water quality baseline data for the Arctic National Wildlife Refuge, Alaska, 1988-1989. Vol.2, Raw data. Fairbanks, Alaska: Ecological Services, U.S. Fish and Wildlife Service. Technical Report NAES-TR-93-03.

TAYLOR, H.E., and GARBARINO, J.R. 1991. The measurement of trace metals in water resource monitoring samples by inductively coupled plasma-mass spectrometry. Spectrochimica Acta Reviews 14:33-44. 
THOMAS, C.W. 1973. Atmospheric natural aerosols and fallout particulates during 1973 at Richland, Washington and Point Barrow, Alaska. Pacific Northwest Laboratory Annual Report. Part 3. (Abstract only)

U.S. ENVIRONMENTAL PROTECTION AGENCY. 1994. Appendix B to Part 136, Definition and procedure for determination of the method detection limit. 7-1 -94 Edition, Federal Register. 635-637.

WALLEN, C.C. 1986. Conclusions from the Arctic Atmospheric Pollution Conference. In: Stonehouse, B., ed. Arctic air pollution. Cambridge, England: Cambridge University Press. 187-196.

WEISS, H.V., BERTINE, K.K., KOIDE, M., and GOLDBERG, E.D. 1975. The chemical composition of a Greenland glacier. Geochimica et Cosmochimica Acta 39:1-10.

WEISS, H.V., HERRON, M.M., and LANGWAY, C.C., Jr. 1978. Natural enrichment of elements in snow. Nature 274:352-353.

WELCH, H.E., MUIR, D.C.G., BILLECK, B.N., LOCKHART, W.L., BRUNSKILL, G.J., KLING, H.J., OLSON, M.P., and LEMOINE, R.M. 1991. Brown snow: A long-range transport event in the Canadian Arctic. Environmental Science and Technology 25:280-286.
WEST, R.L., and SNYDER-CONN, E. 1987. Effects of Prudhoe Bay reserve pit fluids on water quality and macroinvertebrates of arctic tundra ponds in Alaska. Fish and Wildlife Service, U.S. Department of the Interior. Biological Report 87(7):1-48.

WOLFF, E.W., and PEEL, D.A. 1985. The record of global pollution in polar snow and ice. Nature 313:535-540.

WOLFF, E.W., and PEEL, D.A. 1988. Concentrations of cadmium, copper, lead and zinc in snow from near Dye 3 in South Greenland. Annals of Glaciology 10:193-197.

WOODWARD, D.F., SNYDER-CONN, E., RILEY, R.G., and GARLAND, T.R. 1988. Drilling fluids and the arctic tundra of Alaska: Assessing contamination of wetlands habitat and the toxicity to aquatic invertebrates and fish. Archives of Environmental Contamination and Toxicology 17:683-697.

WRIGHT, R.F., and DOVLAND, H. 1978. Regional surveys of the chemistry of the snowpack in Norway, late winter 1973, 1974, 1975 and 1976. Atmospheric Environment 12:1755-1768.

YEN, T.S. 1975. The role of trace metals in Petroleum. Ann Arbor, Michigan: Ann Arbor Scientific Publishers. 